\title{
Global and Regional Financial Integration in East Asia and the ASEAN*
}

\author{
Renée Fry-McKibbin\%,\#, Cody Yu-Ling Hsiao "\% and Vance L. Martin ${ }^{\S, \%,}$ \\ ${ }^{\%}$ Centre for Applied Macroeconomic Analysis (CAMA) \\ \#Crawford School of Public Policy, Australian National University \\ 'School of Business, Macau University of Science and Technology \\ ${ }^{\S}$ Department of Economics, The University of Melbourne
}

May 2017

\begin{abstract}
Financial integration is East Asia and the ASEAN nations is investigated using a new approach based on entropy theory. An important advantage of the proposed framework is that it takes into account changes in integration arising from higher order moments including coskewness and cokurtosis as well as more traditional measures based on second order moments. The analysis focusses on the role of the U.S. in understanding changes in global integration over time, as well as changes in regional integration arising from China. Using daily stock returns from 1997 to 2016, the empirical results show an overall trend to improvements in financial integration over time with deviations from the trend occurring during periods of financial crises in Asia in 1997-98, the U.S. in 2007-10 and the recent European debt crisis. The influence of the Chinese economy mainly through its trading linkages is found to be an important determinant of financial integration over time both regionally as well as globally.
\end{abstract}

Keywords: Integration, Entropy, East Asia, ASEAN, China

JEL Classification: C12, F30

*The authors gratefully acknowledge ARC Discovery Project funding DP0985783 and DP120103443, and Macau University of Science and Technology Faculty Research Grant FRG 17-019MSB. Corresponding author is Cody Yu-Ling Hsiao, School of Business, Macau University of Science and Technology, Avenida Wai Long, Taipa, Macau. Tel: +853 8897 2064. E: ylhsiao@must.edu.mo. Other author email addresses are: renee.mckibbin@anu.edu.au, vance@unimelb.edu.au. 


\section{Introduction}

Although welcomed, the economic rise of the People's Republic of China in the East Asian region adds an extra element of complexity to regional economic frameworks and objectives that have been developing particularly in South East Asia since the Asian Financial Crisis in 1997-1998. China, Japan and South Korea along with the ASEAN nations (Brunei Darussalam, Cambodia, Indonesia, Lao PDR, Malaysia, Myanmar, the Philippines, Singapore, Thailand and Vietnam) in a group labeled ASEAN +3 have explored a range of important policies designed to open up the region since this time, and in particular to insulate the region from crises like that in 1997-1998.

Since 1997 a substantial number of regionally based free trade agreements have been signed or are in negotiation (including the China-Japan-South Korea proposal). In 2000, the Chiang Mai initiative was designed consisting of a range of policies, including bilateral currency swaps which provided a mechanism of self insurance to avoid reliance on institutions such as the IMF. A decade after the 1997-1998 Asian financial crisis, the ASEAN countries in 2008 announced the formation of the ASEAN economic community by 2015 that included the free flow of goods, services, investment and skilled labour, as well as a freer flow of capital (ASEAN 2008). One of the key characteristics of the blueprint and implicitly in the other policy initiatives developed, was for a region fully integrated into the global economy (Jeon et al., 2006; Kim et al., 2008).

Almost 20 years after the Asian financial crisis and the passing of the 2015 blueprint timeframe, makes it pertinent to examine the progress of the goals of cooperation that have developed within East and South East Asia. The aim of the present paper is to examine changes in financial market integration over time within the Asian region, and between Asia and the rest of the world. Motivated by the approach of Bekaert and Harvey (1995) financial market integration is measured in terms of pricing the relative exposure to risks from local and global factors. However, unlike Bekaert and Harvey (1995) who focus solely on expected returns the present approach adopts a broader class of joint distribution of asset returns that allows for higher order moments including coskewness and cokurtosis as well as more traditional measures based on second order moments (as adopted by Lien, 2016; Diebold and Yilmaz, 2009). The role of higher order moment channels linking asset markets is emphasized by Harvey and Siddique (2000), Smith (2007), Fry, Martin and Tang (2010) and Fry-McKibbin, Martin and Tang (2014), who allow for conditional coskewness in asset pricing models, 
and Fry-McKibbin and Hsiao (2016) and Fry-McKibbin, Hsiao and Martin (2016) who also include cokurtosis. An allowance for higher order moments in asset returns is considered to be especially important given the well-known empirical property that the distribution of asset returns exhibits leptokurtosis, particularly during periods of financial market stress which is a feature of financial markets over the past decade (Beine, Cosma and Vermeulen, 2010).

To identify the size and direction of change in financial market integration over time arising from changes in higher order moment behavior linking asset markets, a measure of integration based on entropy is proposed. In the extreme case of no integration between the two asset markets, the returns are independent of each other. For higher levels of integration the joint distribution changes with some regions of the distribution characterized by greater mass corresponding to where joint movements become more likely, and other regions by lower mass where joint movements are less likely. As the mass of the joint distribution becomes more narrowly located within a smaller region, the two asset markets become increasingly integrated.

An important advantage of the proposed approach is that the entropy measure of integration does not rely on specifying a particular parametric model of financial integration as is adopted in Bekaert and Harvey (1995), Halldane and Hall (1991) and Solnik and Roulet (2000) for example, which, in turn, require imposing strong parametric restrictions on the form of the joint distribution of asset returns (see also Yu, Fung and Tam, 2010). Rather, the approach allows for changes in financial integration over time through changes in the overall shape of the joint probability distribution. A further advantage of the entropy measure of integration is that by including higher order comoment channels linking asset markets in the joint probability distribution the approach nests previous financial integration measures based correlation and covariances (see also Fratzcher, 2002; Dumas, Harvey, and Ruiz, 2003; Kim, Moshirian and Wu, 2005; and Pukthuanthong and Roll, 2009).

An alternative approach to assess changes in integration to the empirical models discussed here is to analyze directly the changes in economic impediments to cross border capital flows, mainly imposed through economic policy settings (Sohn and Heo, 2016). The range of policies available is vast and examples include changes in capital controls, changes in foreign equity ownership restrictions and the effects of free trade agreements, particularly on foreign investment. Although these are sensible measures to examine, they are not necessarily perfect indicators of integration as it is possible to 
access foreign markets in indirect ways such as through American Depositary Receipts (Bekaert et al., 2005). Others such as Guillaumin (2009) and Chan, Dhang and Lai (2016) chose to interpret integration through the lens of the saving-investment dependence relationships between countries. These alternative methods are complementary in nature. Indeed recognition of this literature is allowed for at least indirectly, by identifying factors based on trade, as well as business cycles and capital mobility through interest rate spreads, which help to identify movements in the computed entropy integration measure over time.

Applying the entropy measure of integration to daily equity returns of East Asian and ASEAN countries as well as the U.S. over the period 1997 to 2016, reveals strong empirical evidence of a general positive trend in both global and regional financial integration in Asian equity markets, with temporary deviations from trend occurring during periods of global financial crises. There is also evidence that financial integration both globally and regionally, has recently deteriorated during the last couple of years between 2014 and 2016. A key empirical result of the paper is that trade with China as well as the size of the Chinese economy have a significantly positive effect on regional integration. Interestingly, capital mobility is not in general found to be an important determinant of financial integration.

The rest of the paper proceeds as follows. Section 2 provides some background indicators of integration in East Asia and ASEAN together with dynamic estimates of equity returns correlations. The entropy measure of integration is discussed in Section 3 , which is applied to measure global financial integration in Section 4 and regional financial integration in Section 5 with an emphasis on the role of China. Concluding comments are given in Section 6.

\section{Background}

This section presents some basic indicators of integration in the East Asian and ASEAN regions. The East Asian countries consist of China, Hong Kong, Macau, Japan, South Korea, Mongolia and Taiwan. ${ }^{1}$ The ASEAN nations are Brunei Darussalam, Cambodia, Indonesia, Lao PDR, Malaysia, Myanmar, the Philippines, Singapore, Thailand and Vietnam. The U.S. is chosen as the global market proxy. Table 1 presents a summary of the data availability for the East Asian and ASEAN equity markets over

\footnotetext{
${ }^{1}$ North Korea is excluded from the analysis.
} 
Table 1:

Equity market sample periods for East Asia and the ASEAN.

\begin{tabular}{|c|c|c|}
\hline Region & Country & Sample Period \\
\hline \multirow[t]{7}{*}{ East Asia } & China & 1 Jan 1997 - 6 Apr 2016 \\
\hline & Hong Kong & 1 Jan 1997 - 6 Apr 2016 \\
\hline & Macau & n.a. \\
\hline & Japan & 1 Jan 1997 - 6 Apr 2016 \\
\hline & South Korea & 1 Jan 1997 - 6 Apr 2016 \\
\hline & Mongolia & 4 Jan 1999 - 6 Apr 2016 \\
\hline & Taiwan & 1 Jan 1997 - 6 Apr 2016 \\
\hline \multirow[t]{10}{*}{ ASEAN } & Brunei Darussalam & n.a. \\
\hline & Cambodia & 18 Apr $2012-6$ Apr 2016 \\
\hline & Indonesia & 1 Jan 1997 - 6 Apr 2016 \\
\hline & Lao PDR & 11 Jan 2011 - 6 Apr 2016 \\
\hline & Malaysia & 1 Jan 1997 - 6 Apr 2016 \\
\hline & Myanmar & n.a. \\
\hline & Philippines & 1 Jan 1997 - 6 Apr 2016 \\
\hline & Singapore & 1 Jan 1997 - 6 Apr 2016 \\
\hline & Thailand & 1 Jan 1997 - 6 Apr 2016 \\
\hline & Vietnam & 28 Jul 2000 - 6 Apr 2016 \\
\hline
\end{tabular}

Note: This table summarizes the data availability for the East Asian and ASEAN equity markets during the period of January 1, 1997 to April 6, 2016. The data are collected from Bloomberg.

the period January 1, 1997 to April 6, 2016, with plots of the log of the equity indices presented in Figure 1. Many of the smaller countries opened equity markets relatively recently, with Mongolia opening in 1999, Vietnam in 2000, Lao PDR in 2011 and Cambodia in 2012. Myanmar opened its equity market in 2016 while Brunei Darussalam plans to open its equity market in 2017. Macau does not have it's own equity market. The analysis in this paper focuses on the period for those countries having an operating equity market from January 1, 1997 to 6 April 2016. A description of all data sources are given in Table 1A in Appendix A.

A snap shot of several indicators commonly used to measure integration are presented in Section 2.1 to give some context to the dynamics of the closeness of economic ties between countries within the region and with the world. The indicators capture 
the main fundamentals based-drivers of integration which are through investment and trade channels, as well through openness. The results of the estimation of bivariate DCC GARCH models of the returns are also presented in Section 2.2 as a preliminary gauge of change in integration over the sample period.

\section{$2.1 \quad$ Indicators}

Portfolio Investment Tables 2 and 3 present data for the East Asian and ASEAN countries respectively from the IMF coordinated portfolio investment survey which began in 2001. The survey is a voluntary survey capturing portfolio investment flows between countries, and the tables provide the proportion of total world portfolio outflows and inflows that each country has with the U.S., within their own country grouping (East Asia or ASEAN) as well as with the rest of East Asia or ASEAN. As the survey is voluntary and only began in 2001, there are potentially some limitations with the data, nonetheless it is indicative of the trends in portfolio investment and as an indicator of integration in capital markets in general. The table for the East Asian countries (Table 2) shows that for the two largest global financial centers of Japan and Korea, the portfolio flows inbound and outbound are dominated by the U.S. accounting for around $40 \%$ of portfolio flows. This proportion has been roughly the same over time apart from the 2010 downturn in the U.S. where Korea's portfolio investment flows turned towards East Asia before returning to the pre-downturn level. Hong Kong is also dominated by the U.S. on the portfolio inflow side but invests more in East Asia.

The dominance of the U.S. amongst the East Asian and ASEAN counties is perhaps indicating more global than regional integration for those with a larger financial centre. China only recently began reporting (although there is some incomplete reporting from the side of the counterpart countries), with the U.S. being the recipient of portfolio flows from China, and China being the recipient from East Asia in 2014. The results for the ASEAN countries in Table 3 show that for Indonesia, Malaysia (outflow only), Singapore and the Philippines, the U.S. comprises a larger share of portfolio investment inflows and outflows while Malaysia (inflow only) and Thailand are focussed more towards the ASEAN countries. The smaller East Asian and ASEAN countries of Macao, Mongolia, Brunei, Cambodia, Laos and Myanmar, either don't report data or receive portfolio inflows predominantly from their own region. 

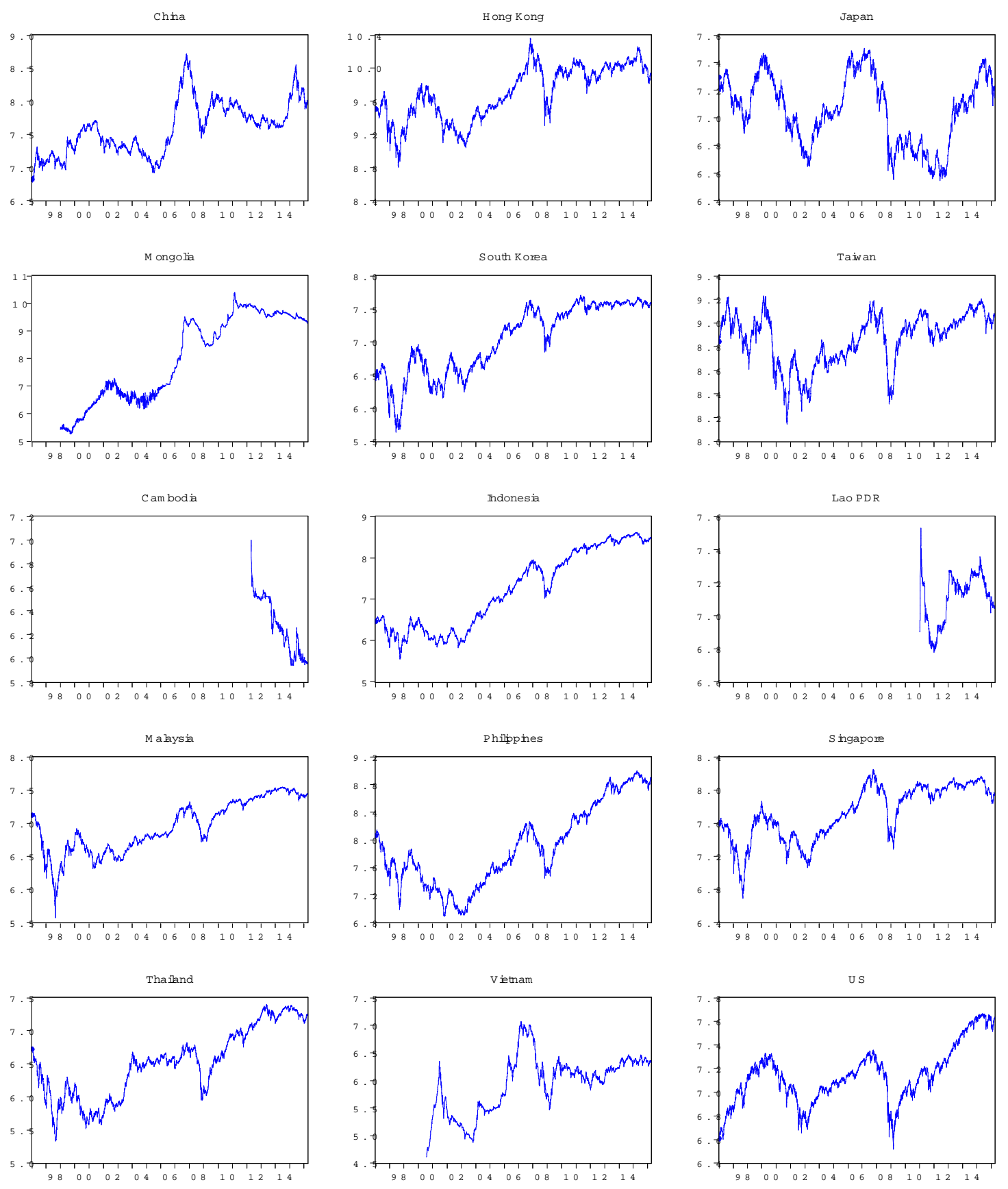

Figure 1: East Asian, ASEAN and US daily equity market indices (natural logs), Jan 1, 1997 to April 6, 2016. 
Table 2:

Share of foreign portfolio investment of East Asian countries as a percentage of total world portfolio investment, 2001 to 2014 .

\begin{tabular}{|c|c|c|c|c|c|c|c|c|c|}
\hline \multirow[t]{2}{*}{ Country } & \multirow[t]{2}{*}{ Partner } & \multicolumn{4}{|c|}{ Outward } & \multicolumn{4}{|c|}{ Inward } \\
\hline & & 2001 & 2004 & 2010 & 2014 & 2001 & 2004 & 2010 & 2014 \\
\hline \multirow[t]{3}{*}{ China } & U.S. & n.a. & n.a. & n.a. & 40.69 & 14.71 & 18.67 & 20.38 & 14.49 \\
\hline & East Asia & n.a. & n.a. & n.a. & 23.33 & n.a. & n.a. & n.a. & 48.96 \\
\hline & ASEAN & n.a. & n.a. & n.a. & 2.32 & 7.90 & 5.08 & 8.14 & 9.23 \\
\hline \multirow[t]{3}{*}{ Hong Kong } & U.S. & 19.09 & 14.88 & 9.96 & 8.76 & 33.14 & 29.87 & 41.97 & 35.93 \\
\hline & East Asia & 11.07 & 12.29 & 25.36 & 36.03 & 7.71 & 9.62 & 8.67 & 8.98 \\
\hline & ASEAN & 3.64 & 3.73 & 2.56 & 2.47 & 5.15 & 7.21 & 5.62 & 8.55 \\
\hline \multirow[t]{3}{*}{ Macao } & U.S. & 9.61 & 13.39 & 8.10 & 5.66 & n.a. & n.a. & n.a. & n.a. \\
\hline & East Asia & 37.41 & 31.71 & 41.72 & 68.39 & n.a. & n.a. & n.a. & n.a. \\
\hline & ASEAN & 1.29 & 1.64 & 1.83 & 0.96 & n.a. & n.a. & n.a. & n.a. \\
\hline \multirow[t]{3}{*}{ Japan } & U.S. & 38.01 & 34.55 & 34.02 & 36.29 & 36.58 & 42.59 & 37.60 & 39.09 \\
\hline & East Asia & 2.65 & 0.68 & 0.62 & 1.47 & 0.99 & 1.40 & 1.93 & 2.00 \\
\hline & ASEAN & 0.58 & 0.36 & 0.90 & 1.31 & 1.68 & 1.52 & 0.02 & 0.03 \\
\hline \multirow[t]{3}{*}{ South Korea } & U.S. & 46.85 & 44.89 & 29.07 & 40.72 & 43.33 & 43.15 & 35.89 & 38.29 \\
\hline & East Asia & 9.21 & 5.02 & 20.43 & 13.69 & 7.39 & 3.70 & 4.41 & 8.88 \\
\hline & ASEAN & 12.33 & 2.24 & 2.93 & 2.53 & 4.76 & 6.45 & 8.26 & 9.57 \\
\hline \multirow[t]{3}{*}{ Mongolia } & U.S. & n.a. & n.a. & n.a. & 11.43 & n.a. & n.a. & 2.40 & 0.00 \\
\hline & East Asia & n.a. & n.a. & n.a. & 49.98 & n.a. & n.a. & n.a. & 15.74 \\
\hline & ASEAN & n.a. & n.a. & n.a. & 11.77 & n.a. & n.a. & 0.00 & 0.00 \\
\hline
\end{tabular}

Note: This table reports the proportion of total world portfolio outflows and inflows of East Asian countries with the U.S., East Asia and the ASEAN. The data are collected from the IMF Coordinated Portfolio Investment Survey (CPIS). The CPIS began in 2001 and countries report on a voluntary basis. An n.a. represents either no data are available, or the data are not considered to be reliable. 
Table 3:

Share foreign portfolio investment of ASEAN countries as a percentage of total world portfolio investment, 2001 to 2014.

\begin{tabular}{|c|c|c|c|c|c|c|c|c|c|}
\hline \multirow[t]{2}{*}{ Country } & \multirow[t]{2}{*}{ Partner } & \multicolumn{4}{|c|}{ Outward } & \multicolumn{4}{|c|}{ Inward } \\
\hline & & 2001 & 2004 & 2010 & 2014 & 2001 & 2004 & 2010 & 2014 \\
\hline \multirow[t]{3}{*}{ Brunei } & U.S. & n.a. & n.a. & n.a. & n.a. & 0 & 0 & 0 & 0 \\
\hline & East Asia & n.a. & n.a. & n.a. & n.a. & 0 & 67 & 0 & 0 \\
\hline & ASEAN & n.a. & n.a. & n.a. & n.a. & 0 & 0 & 0 & 35 \\
\hline \multirow[t]{3}{*}{ Cambodia } & U.S. & n.a. & n.a. & n.a. & n.a. & n.a. & n.a. & n.a. & n.a. \\
\hline & East Asia & n.a. & n.a. & n.a. & n.a. & n.a. & n.a. & n.a. & n.a. \\
\hline & ASEAN & n.a. & n.a. & n.a. & n.a. & n.a. & n.a. & n.a. & n.a. \\
\hline \multirow[t]{3}{*}{ Indonesia } & U.S. & 35 & 15 & 17 & 20 & 34 & 29 & 32 & 35 \\
\hline & East Asia & 15 & 4 & 6 & 16 & 4 & 3 & 8 & 6 \\
\hline & ASEAN & 6 & 5 & 12 & 4 & 16 & 14 & 21 & 14 \\
\hline \multirow[t]{3}{*}{ Lao } & U.S. & n.a. & n.a. & n.a. & n.a. & n.a. & n.a. & 0 & 0 \\
\hline & East Asia & n.a. & n.a. & n.a. & n.a. & n.a. & n.a. & 0 & 59 \\
\hline & ASEAN & n.a. & n.a. & n.a. & n.a. & n.a. & n.a. & 65 & 36 \\
\hline \multirow{3}{*}{ Malaysia } & U.S. & 9 & 15 & 21 & 29 & 19 & 22 & 31 & 26 \\
\hline & East Asia & 5 & 9 & 18 & 10 & 24 & 12 & 11 & 11 \\
\hline & ASEAN & 31 & 17 & 31 & 38 & 30 & 29 & 14 & 22 \\
\hline \multirow[t]{3}{*}{ Myanmar } & U.S. & n.a. & n.a. & n.a. & n.a. & 0 & 0 & 0 & n.a. \\
\hline & East Asia & n.a. & n.a. & n.a. & n.a. & 0 & 0 & 0 & n.a. \\
\hline & ASEAN & n.a. & n.a. & n.a. & n.a. & 100 & 92 & 100 & n.a. \\
\hline \multirow[t]{3}{*}{ Philippines } & U.S. & 86 & 65 & 32 & 37 & 31 & 33 & 35 & 33 \\
\hline & East Asia & 2 & 3 & 9 & 14 & 22 & 13 & 10 & 5 \\
\hline & ASEAN & 3 & 1 & 15 & 22 & 11 & 6 & 9 & 13 \\
\hline \multirow{3}{*}{ Singapore } & U.S. & 20 & 26 & 23 & 28 & 45 & 43 & 38 & 35 \\
\hline & East Asia & 17 & 14 & 15 & 17 & 10 & 16 & 16 & 13 \\
\hline & ASEAN & 10 & 9 & 8 & 7 & 1 & 1 & 6 & 9 \\
\hline \multirow[t]{3}{*}{ Thailand } & U.S. & 35 & 28 & 12 & 13 & 22 & 27 & 32 & 36 \\
\hline & East Asia & 16 & 9 & 53 & 27 & 20 & 13 & 6 & 9 \\
\hline & ASEAN & 15 & 13 & 4 & 4 & 20 & 15 & 12 & 9 \\
\hline \multirow[t]{3}{*}{ Vietnam } & U.S. & n.a. & n.a. & n.a. & n.a. & 2 & 1 & 8 & 7 \\
\hline & East Asia & n.a. & n.a. & n.a. & n.a. & 0 & 0 & 2 & 1 \\
\hline & ASEAN & n.a. & n.a. & n.a. & n.a. & 0 & 0 & 1 & 1 \\
\hline
\end{tabular}

Note: This table reports the proportion of total world portfolio outflows and inflows of the ASEAN countries with the U.S., East Asia and the ASEAN. The data are collected from the IMF Coordinated Portfolio Investment Survey (CPIS). The CPIS began in 2001 and countries report on a voluntary basis. An n.a. represents either no data are available, or the data are not considered to be reliable. 
Trade The main vehicle through which the process of integration proceeds is usually thought to be through the development of trade linkages (Athukorala and Yamashita, 2006; Shin and Sohn, 2006; Gaulier, Lemoine and Ünal-Kesenci, 2007; Lee, Huh and Park, 2013; Sohn and Heo, 2016; Sato and Shrestha, 2016; and Yi-fei and Fan, 2016). Tables 4 to 6 present some preliminary statistics on the importance of trade as a percentage of GDP from selected years from 1998 to 2014, as well as the share of each countries trade with the U.S., East Asia and the ASEAN countries expressed in terms of the percentage of total exports or imports of each country. Table 4 shows the importance of trade to most of the economies in the sample, with trade for Hong Kong, Macau, Mongolia, Brunei, Cambodia, Malaysia, Singapore and Thailand being more than $100 \%$ of GDP, and in the case of Hong Kong is more than $400 \%$ of GDP in 2014.

Tables 5 and 6 clearly show that by 2014 trade is mostly local. Generally, the East Asian countries share of exports as a proportion of total exports, and imports as a proportion of total imports is dominated by East Asia, and the bilateral share of trade in the ASEAN countries is dominated by the ASEAN countries. This is not always the case. In 1998, the share of exports with the U.S. is higher than with the regional partners for Macau, Japan and the Philippines. Cambodia is the only country that did not became more regionally oriented by 2014 .

The only country who receives more imports from the U.S. than from their own or neighboring regions is Japan in 1998, although this substantially changes over the 16 year snapshot with Japanese imports from the U.S. falling from $24 \%$ of total imports in 1998 to $9 \%$ in 2014 . The Japanese case is the only example of one of the larger markets having stronger U.S. trade linkages. In contrast, the linkages between the larger markets of Hong Kong and South Korea with the U.S. are evident through portfolio flows. These changes over time provide evidence of the changes in integration of Japan with the region through trade by 2014 .

Chinn-Ito Openness Index One measure of capital account openness over time is the Chinn-Ito index which represents the first principal component of a range of variables in the IMF's Annual Report on Exchange Arrangements and Exchange Restrictions (Chinn and Ito, 2006; 2008). A larger value of the index corresponds to more openness. Table 7 clearly shows that most countries have changed in terms of openness between 1998 and 2013. Those countries with a more open capital account 
Table 4:

Trade as a percentage of GDP for the East Asian and ASEAN countries, 1998 to 2014.

\begin{tabular}{clrrrr}
\hline \hline Region & \multicolumn{1}{c}{ Country } & 1998 & 2004 & 2010 & \multicolumn{1}{c}{2014} \\
\hline East Asia & China & 31.60 & 59.40 & 49.30 & 41.50 \\
& Hong Kong & 248.00 & 364.60 & 432.90 & 439.20 \\
& Macau & 140.40 & 173.70 & 155.80 & 143.90 \\
& Japan & 19.70 & 24.50 & 29.10 & 38.60 \\
& South Korea & 72.90 & 72.80 & 95.70 & 95.90 \\
& Mongolia & 107.40 & 131.30 & 103.40 & 109.50 \\
& Taiwan & n.a. & n.a. & n.a. & n.a. \\
& Brunei Darussalam & 107.90 & 100.60 & 114.30 & 106.60 \\
& Cambodia & 75.60 & 134.50 & 113.60 & 129.00 \\
& Indonesia & 96.20 & 59.80 & 46.70 & 48.20 \\
& Lao PDR & 84.30 & 77.50 & 73.50 & 90.10 \\
& Malaysia & 209.50 & 210.40 & 157.90 & 138.50 \\
& Myanmar & 1.50 & 0.30 & n.a. & n.a. \\
& Philippines & 98.70 & 102.60 & 71.40 & 61.10 \\
& Singapore & 313.90 & 406.30 & 372.10 & 350.90 \\
& Thailand & 100.20 & 127.40 & 126.80 & 131.80 \\
& Vietnam & 97.00 & 122.30 & 152.20 & 169.50 \\
\hline
\end{tabular}

Note: The data are collected from the World Bank World Development Indicators. An n.a. represents either no data are available, or the data are not considered to be reliable. 
Table 5:

Trade shares of the East Asian countries with the U.S., East Asia and the ASEAN, 1998 to 2014. Percentage of total exports or imports of each country.

\begin{tabular}{|c|c|c|c|c|c|c|c|c|c|}
\hline \multirow[t]{2}{*}{ Country } & \multirow[t]{2}{*}{ Partner } & \multicolumn{4}{|c|}{ Exports } & \multicolumn{4}{|c|}{ Imports } \\
\hline & & 1998 & 2004 & 2010 & 2014 & 1998 & 2004 & 2010 & 2014 \\
\hline \multirow{3}{*}{ China } & U.S. & 20.68 & 21.09 & 17.97 & 16.95 & 12.11 & 7.98 & 7.31 & 7.85 \\
\hline & East Asia & 41.13 & 34.42 & 26.03 & 26.41 & 35.83 & 30.11 & 23.42 & 18.91 \\
\hline & ASEAN & 6.00 & 7.23 & 8.76 & 11.60 & 9.00 & 11.23 & 11.07 & 10.60 \\
\hline \multirow{3}{*}{ Hong Kong } & U.S. & 23.43 & 16.95 & 10.97 & 9.32 & 7.46 & 5.34 & 5.38 & 5.21 \\
\hline & East Asia & 41.59 & 52.01 & 59.44 & 60.49 & 58.13 & 60.50 & 58.69 & 58.24 \\
\hline & ASEAN & 5.61 & 6.15 & 6.24 & 7.04 & 9.99 & 11.95 & 17.16 & 13.42 \\
\hline \multirow[t]{3}{*}{ Macau } & U.S. & 47.63 & 48.71 & 11.24 & 2.96 & 4.71 & 4.05 & 5.92 & 6.51 \\
\hline & East Asia & 15.05 & 22.45 & 60.89 & 76.13 & 66.72 & 67.54 & 51.34 & 50.98 \\
\hline & ASEAN & 1.58 & 1.38 & 4.80 & 1.73 & 4.79 & 6.97 & 5.85 & 4.39 \\
\hline \multirow{3}{*}{ Japan } & U.S. & 30.85 & 22.73 & 15.65 & 18.92 & 24.04 & 13.98 & 9.95 & 8.99 \\
\hline & East Asia & 14.99 & 27.18 & 33.07 & 31.38 & 18.17 & 25.96 & 26.45 & 26.59 \\
\hline & ASEAN & 12.03 & 12.90 & 14.66 & 15.16 & 14.14 & 14.82 & 14.55 & 14.26 \\
\hline \multirow[t]{3}{*}{ South Korea } & U.S. & 17.37 & 16.96 & 10.72 & 12.32 & 21.87 & 12.88 & 9.55 & 8.67 \\
\hline & East Asia & 25.33 & 35.35 & 36.56 & 35.84 & 25.57 & 35.20 & 32.42 & 27.71 \\
\hline & ASEAN & 11.56 & 9.47 & 11.41 & 14.77 & 9.80 & 9.97 & 10.37 & 10.16 \\
\hline \multirow[t]{3}{*}{ Mongolia } & U.S. & 8.52 & 17.98 & 0.41 & 0.28 & 7.23 & 4.56 & 3.28 & 3.12 \\
\hline & East Asia & 45.46 & 52.51 & 83.63 & 96.16 & 32.48 & 38.41 & 52.05 & 54.42 \\
\hline & ASEAN & 0.37 & 2.30 & 0.16 & 0.47 & 4.59 & 3.19 & 3.06 & 2.13 \\
\hline
\end{tabular}

Note: As the data for Taiwan is incomplete it is not included here. The data are collected from the IMF Direction of Trade Statistics. 
Table 6:

Trade shares of the ASEAN countries with the U.S., East Asia and the ASEAN, 1998 to 2014. Percentage of total exports or imports of each country.

\begin{tabular}{|c|c|c|c|c|c|c|c|c|c|}
\hline \multirow[t]{2}{*}{ Country } & \multirow[t]{2}{*}{ Partner } & \multicolumn{4}{|c|}{ Exports } & \multicolumn{4}{|c|}{ Imports } \\
\hline & & 1998 & 2004 & 2010 & 2014 & 1998 & 2004 & 2010 & 2014 \\
\hline \multirow{3}{*}{ Brunei } & U.S. & 10.29 & 8.60 & 0.15 & 0.31 & 5.80 & 3.30 & 4.29 & 8.36 \\
\hline & East Asia & 62.96 & 56.92 & 69.05 & 53.37 & 5.40 & 16.33 & 20.46 & 33.00 \\
\hline & ASEAN & 9.32 & 17.13 & 10.53 & 18.75 & 44.37 & 60.12 & 55.44 & 46.57 \\
\hline \multirow[t]{3}{*}{ Cambodia } & U.S. & 31.38 & 46.88 & 34.09 & 23.99 & 3.45 & 1.14 & 2.65 & 2.06 \\
\hline & East Asia & 8.30 & 24.26 & 28.01 & 13.24 & 34.76 & 46.17 & 44.03 & 31.95 \\
\hline & ASEAN & 42.41 & 2.98 & 12.58 & 14.37 & 25.90 & 34.71 & 34.35 & 56.46 \\
\hline \multirow[t]{3}{*}{ Indonesia } & U.S. & 14.42 & 12.28 & 9.06 & 9.39 & 12.88 & 6.95 & 6.94 & 4.60 \\
\hline & East Asia & 31.50 & 37.43 & 35.85 & 30.74 & 25.56 & 26.64 & 34.62 & 34.43 \\
\hline & ASEAN & 19.13 & 18.16 & 21.14 & 22.59 & 16.48 & 24.71 & 28.68 & 28.47 \\
\hline \multirow[t]{3}{*}{ Lao } & U.S. & 5.39 & 0.63 & 2.56 & 0.64 & 0.60 & 0.62 & 0.37 & 0.39 \\
\hline & East Asia & 6.75 & 3.75 & 25.80 & 36.83 & 8.53 & 13.60 & 20.58 & 29.95 \\
\hline & ASEAN & 40.18 & 32.24 & 43.78 & 44.50 & 80.35 & 72.04 & 72.15 & 63.42 \\
\hline \multirow[t]{3}{*}{ Malaysia } & U.S. & 21.62 & 18.77 & 9.55 & 8.41 & 19.62 & 14.63 & 10.64 & 7.66 \\
\hline & East Asia & 20.15 & 26.27 & 31.89 & 31.34 & 31.19 & 33.76 & 32.96 & 31.15 \\
\hline & ASEAN & 24.32 & 25.09 & 25.37 & 27.89 & 22.68 & 24.17 & 27.10 & 25.69 \\
\hline \multirow{3}{*}{ Myanmar } & U.S. & 13.96 & 0.00 & 0.00 & 0.37 & 1.49 & 0.37 & 0.11 & 0.42 \\
\hline & East Asia & 16.77 & 13.16 & 21.88 & 69.03 & 42.67 & 39.75 & 47.30 & 51.88 \\
\hline & ASEAN & 15.53 & 45.23 & 46.62 & 18.25 & 42.93 & 47.31 & 43.57 & 37.52 \\
\hline \multirow[t]{3}{*}{ Philippines } & U.S. & 34.38 & 18.17 & 14.71 & 14.13 & 22.22 & 18.79 & 10.72 & 8.73 \\
\hline & East Asia & 21.73 & 37.55 & 39.11 & 48.69 & 36.29 & 33.64 & 30.45 & 33.35 \\
\hline & ASEAN & 12.95 & 17.23 & 22.47 & 14.91 & 15.00 & 18.98 & 28.04 & 23.90 \\
\hline \multirow[t]{3}{*}{ Singapore } & U.S. & 19.88 & 11.72 & 6.53 & 5.91 & 18.49 & 12.01 & 11.46 & 10.34 \\
\hline & East Asia & 21.04 & 26.18 & 30.89 & 31.75 & 27.31 & 26.58 & 25.45 & 24.41 \\
\hline & ASEAN & 23.93 & 31.55 & 30.26 & 31.22 & 23.34 & 27.35 & 24.00 & 20.60 \\
\hline \multirow[t]{3}{*}{ Thailand } & U.S. & 21.98 & 16.10 & 10.47 & 10.53 & 13.85 & 7.70 & 5.88 & 6.44 \\
\hline & East Asia & 22.87 & 28.41 & 29.32 & 28.12 & 32.63 & 37.59 & 39.36 & 36.77 \\
\hline & ASEAN & 17.24 & 22.01 & 22.93 & 26.11 & 14.68 & 16.84 & 16.60 & 18.01 \\
\hline \multirow[t]{3}{*}{ Vietnam } & U.S. & 5.04 & 18.97 & 20.39 & 20.03 & 2.89 & 3.55 & 4.52 & 4.35 \\
\hline & East Asia & 26.91 & 28.05 & 28.06 & 29.33 & 35.15 & 39.36 & 47.57 & 55.03 \\
\hline & ASEAN & 21.71 & 15.28 & 14.83 & 13.35 & 29.94 & 24.30 & 19.68 & 15.91 \\
\hline
\end{tabular}

Note: The data are collected from the IMF Direction of Trade Statistics. 
Table 7:

The Chinn-Ito financial openness index, 1998 to 2013. A larger value of the index corresponds to greater openness.

\begin{tabular}{clrrrr}
\hline \hline Region & \multicolumn{1}{c}{ Country } & 1998 & 2004 & 2010 & 2013 \\
\hline East Asia & China & -1.19 & -1.19 & -1.19 & -1.19 \\
& Hong Kong & 2.39 & 2.39 & 2.39 & 2.39 \\
& Macau & n.a. & n.a. & n.a. & n.a. \\
& Japan & 2.13 & 2.39 & 2.39 & 2.39 \\
& South Korea & -1.19 & -0.13 & 0.91 & 1.17 \\
& Mongolia & 1.09 & 1.09 & 1.17 & 1.69 \\
& Taiwan & n.a. & n.a. & n.a. & n.a. \\
& Brunei Darussalam & n.a. & n.a. & n.a. & n.a. \\
& Cambodia & -1.89 & 0.21 & 1.17 & 1.17 \\
& Indonesia & 0.91 & 1.09 & 1.09 & -0.13 \\
& Lao PDR & -0.83 & -1.19 & -1.19 & -1.19 \\
& Malaysia & 0.39 & -0.13 & -1.19 & -1.19 \\
& Myanmar & -1.89 & -1.89 & -1.89 & -1.89 \\
& Philippines & 0.04 & 0.04 & -1.19 & -1.19 \\
& Singapore & 1.33 & 2.39 & 2.39 & 2.39 \\
& Thailand & -0.13 & -0.13 & -1.19 & -1.19 \\
& Vietnam & -0.93 & -1.19 & -0.13 & -0.13 \\
& & 2.39 & 2.39 & 2.39 & 2.39 \\
\hline
\end{tabular}

The data are collected from the IMF's Annual Report on Exchange Arrangements and Exchange Restrictions. An n.a. represents either that no data are available, or where the data are not considered to be reliable.

include South Korea, Mongolia, Cambodia, Singapore and Vietnam. Those whose capital account became less open are amongst the ASEAN countries and include Indonesia (in the latter years), Lao PDR, Malaysia, the Philippines and Thailand. China is consistently less open while Hong Kong, Japan, Singapore and the U.S. are consistently open.

\subsection{Dynamic Correlations}

Summary statistics of changes in the daily correlation structure amongst equity markets in East Asia and the U.S. from January 1997 to April 2016, are presented in Figure 2 
Table 8:

Average correlations of 5 East Asian equity markets and the U.S. equity market, March 1997 to April 2016. The dynamic correlations are based on estimating a 6-variate dynamic conditional correlation model (DCC) of Engle (2002) using the equity returns.

\begin{tabular}{lcccccc}
\hline \hline & China & Hong Kong & Japan & South Korea & Taiwan & U.S. \\
\hline China & 1.000 & 0.279 & 0.141 & 0.152 & 0.161 & 0.065 \\
Hong Kong & & 1.000 & 0.469 & 0.529 & 0.448 & 0.302 \\
Japan & & & 1.000 & 0.459 & 0.378 & 0.265 \\
South Korea & & & & 1.000 & 0.487 & 0.258 \\
Taiwan & & & & & 1.000 & 0.197 \\
U.S. & & & & & 1.000 \\
\hline
\end{tabular}

with sample average correlations given in Table 8. The dynamic correlations are based on estimating a 6-variate dynamic conditional correlation model (DCC) of Engle (2002) using the equity returns of 5 East Asian countries consisting of China, Hong Kong, Japan, South Korea and Taiwan, as well as the U.S. equity returns. The DCC model is also used by Yu, Fung and Tam (2010) and Moore and Wang (2014) to understand financial integration amongst selected Asian countries. The dynamic correlations are presented in the upper triangular set of figures, with the conditional variances given down the main diagonal and finally the conditional covariances are given in the lower triangular set of figures. The conditional variances show that all equity markets were affected by the financial crisis in the U.S. from 2008-2010. China also experiences increases in volatility at the end of the sample period in early 2016 which the other equity markets do not appear to experience. The correlations tend to move within the range of \pm 0.5 for all pairs of countries over the sample period without demonstrating any clear trend over time.

Dynamic estimates of the correlations for the equity markets of the ASEAN 5 countries: Indonesia, Malaysia, Philippines, Singapore, Thailand, together with the U.S. are presented in Figure 3 with sample average correlations given in Table 9. The patterns of the correlations in general for the East Asian countries are similar to those of the ASEAN countries. 

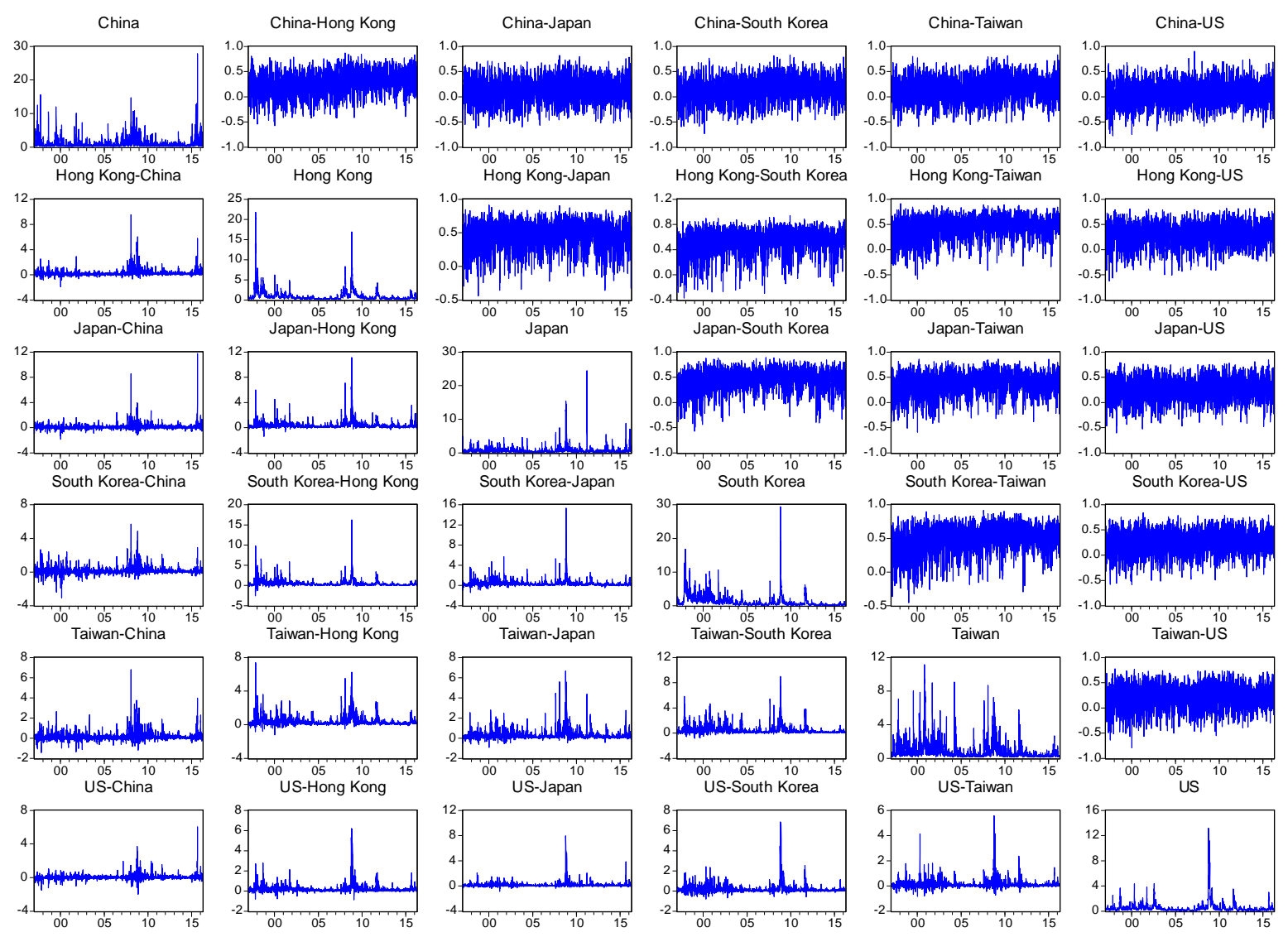

Figure 2: Dynamic conditional correlations (upper triangle), conditional variances (digaonal) and conditional covariances (lower triangle) of 5 East Asian stock markets and the U.S. stock market, March 1997 to April 2016.

Table 9:

Average correlations of 5 ASEAN equity markets and the U.S. equity market, March 1997 to April 2016. The dynamic correlations are based on estimating a 6-variate dynamic conditional correlation model (DCC) of Engle (2002).

\begin{tabular}{lcccccc}
\hline \hline & Indonesia & Malaysia & Philippines & Singapore & Thailand & U.S. \\
\hline Indonesia & 1.000 & 0.379 & 0.348 & 0.428 & 0.372 & 0.175 \\
Malaysia & & 1.000 & 0.329 & 0.434 & 0.349 & 0.167 \\
Philippines & & & 1.000 & 0.361 & 0.335 & 0.186 \\
Singapore & & & & 1.000 & 0.416 & 0.303 \\
Thailand & & & & & 1.000 & 0.191 \\
U.S. & & & & & 1.000 \\
\hline
\end{tabular}



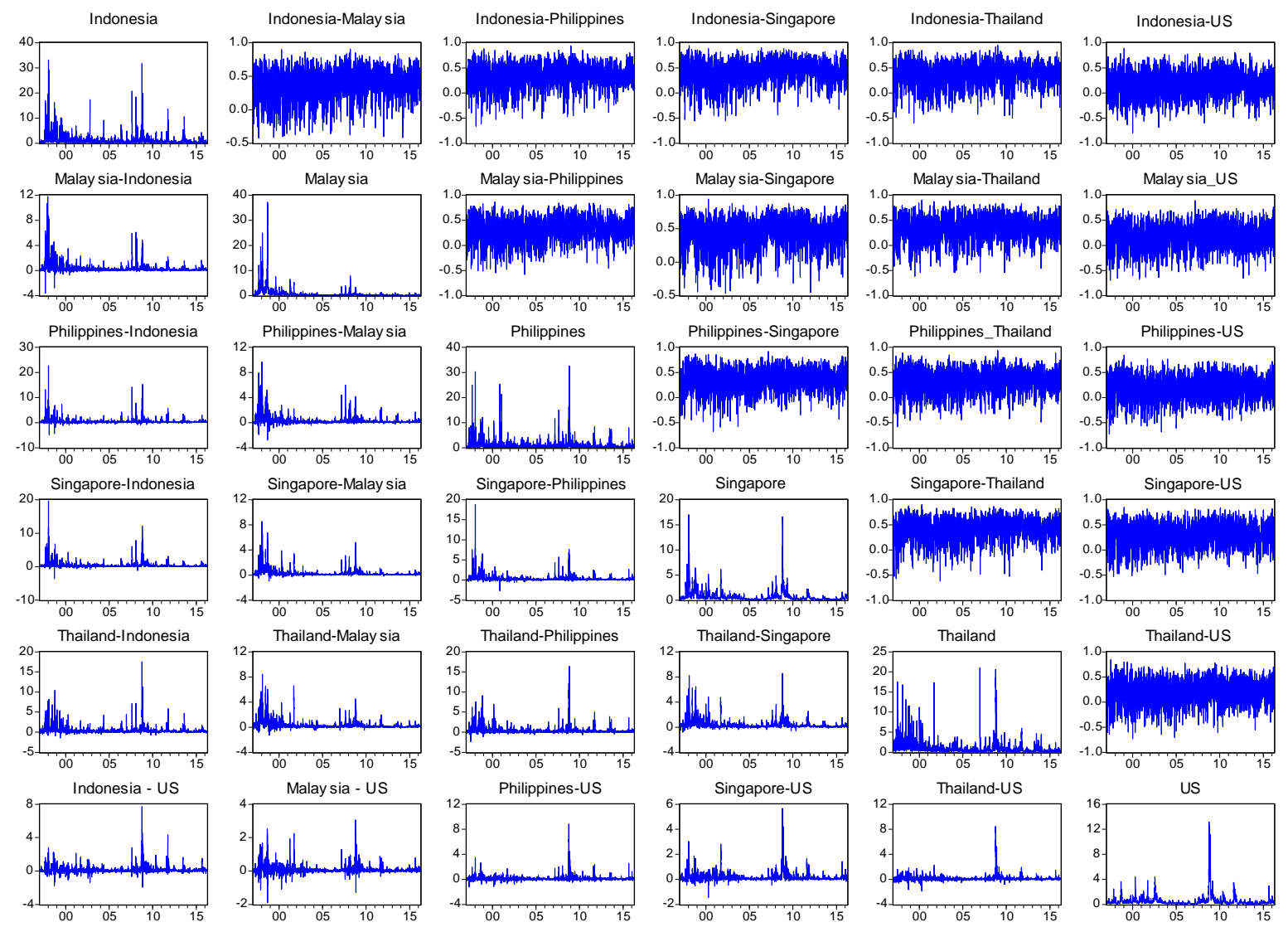

Figure 3: Dynamic conditional correlations (upper triangle), conditional variances (digaonal) and conditional covariances (lower triangle) of 5 ASEAN stock markets and the U.S. stock market, March 1997 to April 2016. 


\section{Entropy Measure of Integration}

The proposed measure of integration is based on entropy theory which takes into account the joint distribution of asset markets to determine their degree of interaction. In the extreme case of no integration so asset markets are segmented, movements in the asset returns of one market are independent of the movements in returns of another market. If, however markets are integrated so movements in asset returns of one market impact upon another market, the joint distribution will exhibit higher mass in some regions and lower mass in other regions. As the mass of the joint distribution becomes located in a smaller region, the two asset markets become increasingly integrated.

The measure of integration is defined formally as the negative of the expected value of the natural logarithm of the distribution of asset returns

$$
\Psi=-E\left[\ln f\left(r_{w}, r_{i} ; \Theta\right)\right]=-\iint\left(\ln f\left(r_{w}, r_{i} ; \Theta\right)\right) f\left(r_{w}, r_{i} ; \Theta\right) d r_{w} d r_{i}
$$

where $f\left(r_{w}, r_{i} ; \Theta\right)$ represents the bivariate asset return probability distribution between the world $\left(r_{w}\right)$ and the $i^{\text {th }}$ country $\left(r_{i}\right)$ with parameter vector $\Theta$. Where the probability of returns moving together is extremely low the integration measure $\Psi$ becomes relatively high. In the extreme case where movements in asset returns are independent the joint probability distribution $f\left(r_{w}, r_{i} ; \Theta\right)$ equals the product of the two marginal distributions $f\left(r_{w} ; \Theta_{w}\right) f\left(r_{i} ; \Theta_{i}\right)$, with $\Theta_{w}$ and $\Theta_{i}$ representing the respective parameters of the two marginal distributions. The entropy measure of integration in (1) now becomes

$$
\begin{aligned}
\Psi= & -\iint\left(\ln f\left(r_{w} ; \Theta_{w}\right) f\left(r_{i} ; \Theta_{i}\right)\right) f\left(r_{w} ; \Theta_{w}\right) f\left(r_{i} ; \Theta_{i}\right) d r_{w} d r_{i} \\
= & -\int\left(\ln f\left(r_{w} ; \Theta_{w}\right)\right) f\left(r_{w} ; \Theta_{w}\right) d r_{w} \int f\left(r_{i} ; \Theta_{i}\right) d r_{i} \\
& -\int\left(\ln f\left(r_{i} ; \Theta_{i}\right)\right) f\left(r_{i} ; \Theta_{i}\right) d r_{i} \int f\left(r_{w} ; \Theta_{w}\right) d r_{w} \\
= & -\int\left(\ln f\left(r_{w} ; \Theta_{w}\right)\right) f\left(r_{w} ; \Theta_{w}\right) d r_{w}-\int\left(\ln f\left(r_{i} ; \Theta_{i}\right)\right) f\left(r_{i} ; \Theta_{i}\right) d r_{i},
\end{aligned}
$$

which is the sum of the two separate entropy measures for $r_{w}$ and $r_{i}$. Equation (2) represents the maximum entropy value and corresponds to the two asset markets being segmented as a result of the independence condition. Where the probability mass of returns becomes more and more concentrated in certain regions the integration measure $\Psi$ in (1) becomes smaller. In the extreme case where the surface mass of the joint probability distribution represents a one-dimensional relationship between the 
two asset returns, the two markets are perfectly integrated as knowing the realization of one asset market provides knowledge of the return on the other asset market with perfect certainty.

To implement the entropy measure of financial integration the distribution $f\left(r_{w}, r_{i} ; \Theta\right)$ underlying the joint returns is specified as the generalized exponential distribution as it is able to account for higher order comoments, including coskewness and cokurtosis (Fry, Martin and Tang, 2010); see also Cobb, Koppstein and Chen, 1983; Lye and Martin, 1993 who studied univariate the properties of the univariate generalized normal distribution. The general form of this joint distribution is

$$
f\left(r_{w}, r_{i} ; \Theta\right)=\exp (h-\eta)
$$

where $h=h\left(r_{w}, r_{i} ; \Theta\right)$ and $\eta=\eta(\Theta)$ is a normalizing constant defined as

$$
\eta=\ln \iint \exp (h) d r_{w} d r_{i}
$$

to ensure that the joint probability density integrates to unity. An important feature of using the generalized exponential family of distributions in (3) is that the entropy measure of integration in (1) has the convenient form

$$
\Psi=\eta-E[h]
$$

as the normalizing constant $\eta$ in (4) by definition is independent of $r_{w}$ and $r_{i}$.

If (3) represents the bivariate generalized normal distribution then the form of $h$ in the exponent of $(3)$, is

$$
\begin{aligned}
h= & -\frac{1}{2}\left(\frac{1}{1-\rho^{2}}\right)\left(\left(\frac{r_{w}-\mu_{w}}{\sigma_{w}}\right)^{2}+\left(\frac{r_{i}-\mu_{i}}{\sigma_{i}}\right)^{2}-2 \rho\left(\frac{r_{w}-\mu_{w}}{\sigma_{w}}\right)\left(\frac{r_{i}-\mu_{i}}{\sigma_{i}}\right)\right) \\
& +\theta_{1}\left(\frac{r_{w}-\mu_{w}}{\sigma_{w}}\right)^{1}\left(\frac{r_{i}-\mu_{i}}{\sigma_{i}}\right)^{2}+\theta_{2}\left(\frac{r_{w}-\mu_{w}}{\sigma_{w}}\right)^{2}\left(\frac{r_{i}-\mu_{i}}{\sigma_{i}}\right)^{1} \\
& +\theta_{3}\left(\frac{r_{w}-\mu_{w}}{\sigma_{w}}\right)^{1}\left(\frac{r_{i}-\mu_{i}}{\sigma_{i}}\right)^{3}+\theta_{4}\left(\frac{r_{w}-\mu_{w}}{\sigma_{w}}\right)^{3}\left(\frac{r_{i}-\mu_{i}}{\sigma_{i}}\right)^{1} \\
& +\theta_{5}\left(\frac{r_{w}-\mu_{w}}{\sigma_{w}}\right)^{2}\left(\frac{r_{i}-\mu_{i}}{\sigma_{i}}\right)^{2} .
\end{aligned}
$$

The first part of the expression on the right-hand side of $h$ corresponds to the bivariate normal distribution which is obtained by imposing the restrictions $\theta_{1}=\theta_{2}=\theta_{3}=\theta_{4}=$ $\theta_{5}=0$. For this particular case there is a closed-form solution of integration given by

$$
\Psi=1+\ln (2 \pi)+\frac{1}{2} \ln \left(\sigma_{w} \sigma_{i}\left(1-\rho^{2}\right)\right) .
$$


The next two terms on the right-hand side of (6) capture coskewness which are controlled by the parameters $\theta_{1}$ and $\theta_{2}$. These terms represent the interaction between the mean and the variance of the asset returns in the equity markets of country $i$ and the world. The next three terms capture cokurtosis which are controlled by the parameters $\theta_{3}, \theta_{4}$ and $\theta_{5}$. The term $\left(\frac{r_{w}-\mu_{w}}{\sigma_{w}}\right)^{1}\left(\frac{r_{i}-\mu_{i}}{\sigma_{i}}\right)^{3}$ represents the interaction between the mean of world returns and skewness in country $i$, while $\left(\frac{r_{w}-\mu_{w}}{\sigma_{w}}\right)^{3}\left(\frac{r_{i}-\mu_{i}}{\sigma_{i}}\right)^{1}$ captures the interaction between skewness in world returns and the mean returns in country $i$. The final cokurtosis term is $\left(\frac{r_{w}-\mu_{w}}{\sigma_{w}}\right)^{2}\left(\frac{r_{i}-\mu_{i}}{\sigma_{i}}\right)^{2}$ captures the interaction between the volatilities of returns in the world and country asset markets. Using the expression (6) in (5) provides a natural decomposition of the measure of integration in terms of second-order and higher-order moments

$$
\begin{array}{rlll}
\Psi=1+\eta & 1+\theta_{1} E\left[\left(\frac{r_{w}-\mu_{w}}{\sigma_{w}}\right)^{1}\left(\frac{r_{i}-\mu_{i}}{\sigma_{i}}\right)^{2}\right] & & \text { [Coskewness] } \\
-\theta_{2} E\left[\left(\frac{r_{w}-\mu_{w}}{\sigma_{w}}\right)^{2}\left(\frac{r_{i}-\mu_{i}}{\sigma_{i}}\right)^{1}\right] & & \text { [Coskewness] } \\
-\theta_{3} E\left[\left(\frac{r_{w}-\mu_{w}}{\sigma_{w}}\right)^{1}\left(\frac{r_{i}-\mu_{i}}{\sigma_{i}}\right)^{3}\right] & & \text { [Cokurtosis] } \\
-\theta_{4} E\left[\left(\frac{r_{w}-\mu_{w}}{\sigma_{w}}\right)^{3}\left(\frac{r_{i}-\mu_{i}}{\sigma_{i}}\right)^{1}\right] & & \text { [Cokurtosis] } \\
-\theta_{5} E\left[\left(\frac{r_{w}-\mu_{w}}{\sigma_{w}}\right)^{2}\left(\frac{r_{i}-\mu_{i}}{\sigma_{i}}\right)^{2}\right] . & & \text { [Covolatility] }
\end{array}
$$

The properties of the integration measure in (8) are highlighted in Figures 4 to 6 which contain the joint probability distribution as well as a contour plot giving the combination of asset returns yielding equal probabilities. Figure 4 provides the base case of market segmentation where the two returns are independent of each other resulting in the equi-probability contours being concentric circles. In this case the joint probability distribution is the product of the two marginal distributions whereby shocks to world returns $\left(r_{w t}\right)$ have no effect on the probability distribution of equity returns in country $i$.

The effect of market integration is shown in Figure 5 where the mass of the joint distribution is stretched over the quadrants corresponding to where $r_{w}$ and $r_{i}$ have the same sign, resulting in the equi-probability contours having an ellipsoidal shape. A 

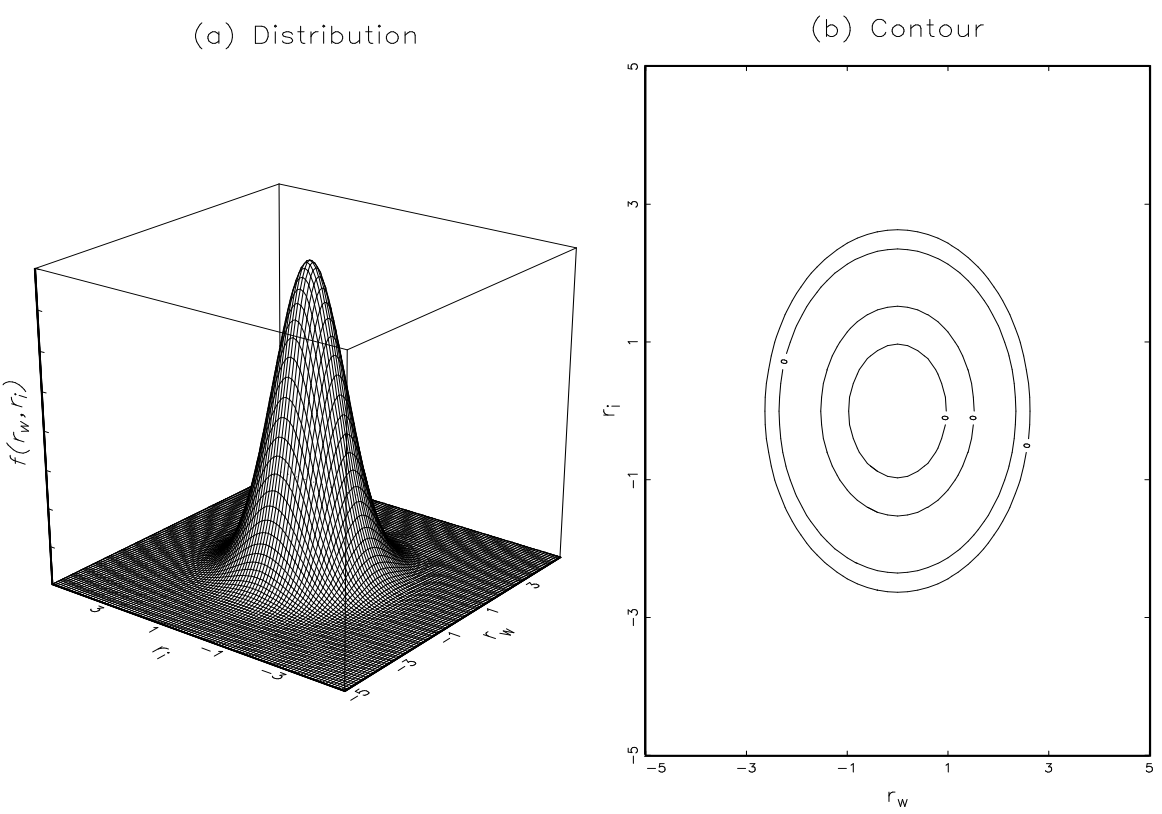

Figure 4: Market segmentation - bivariate normal with $(\rho=0.0) . \Psi=2.8378$.

positive (negative) shock in world returns now has a higher probability of increasing (decreasing) returns in country $i$. The relatively tighter mass of the joint probability distribution raises the degree of certainty between the two asset returns resulting in an improvement in integration with the integration measure decreasing from $\Psi=2.8378$ corresponding to the case of market segmentation in Figure 4, to $\Psi=2.3270$.

The effect of coskewness on the distribution is demonstrated in Figure 6 where $\theta_{2}$ in (6) is increased from $\theta_{2}=0.0$ to $\theta_{2}=0.4$. For decreasing levels of volatility in world returns the joint distribution becomes relatively more compact in the region as returns in country $i$ become more and more negative. Alternatively, the joint distribution becomes more spread out as returns in country $i$ become more and more positive.

To evaluate the integration measure $\Psi(\Theta)$ the unknown parameters are chosen to maximize the log-likelihood function of the bivariate generalized normal distribution with the measure of integration computed as the negative of the log-likelihood function evaluated at the maximum likelihood estimates $\Theta$. For further technical details see Fry, Martin and Tang (2010), Fry-McKibbin and Hsiao (2016) regarding testing of higher order moments. To allow for variations over time of the entropy measure of integration a number of possibilities exist. The approach adopted here follows Diebold and Yilmaz (2009) by performing a rolling window over time and computing the maximum likelihood estimates for each window and the subsequent measure of integration 
(a) Distribution

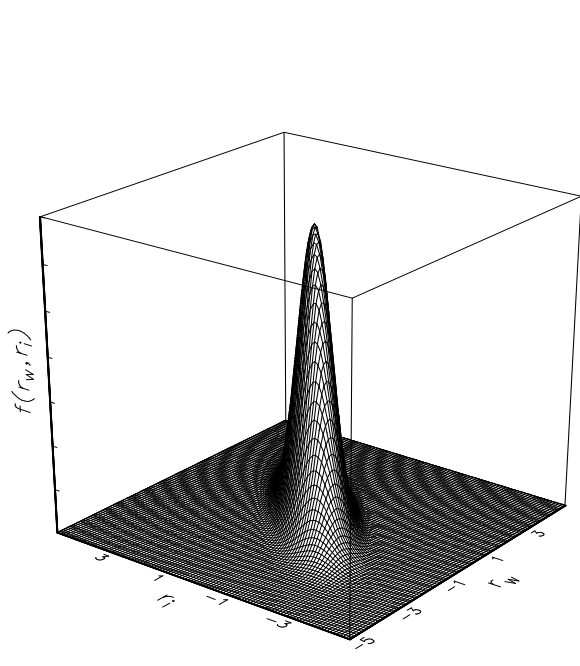

(b) Contour

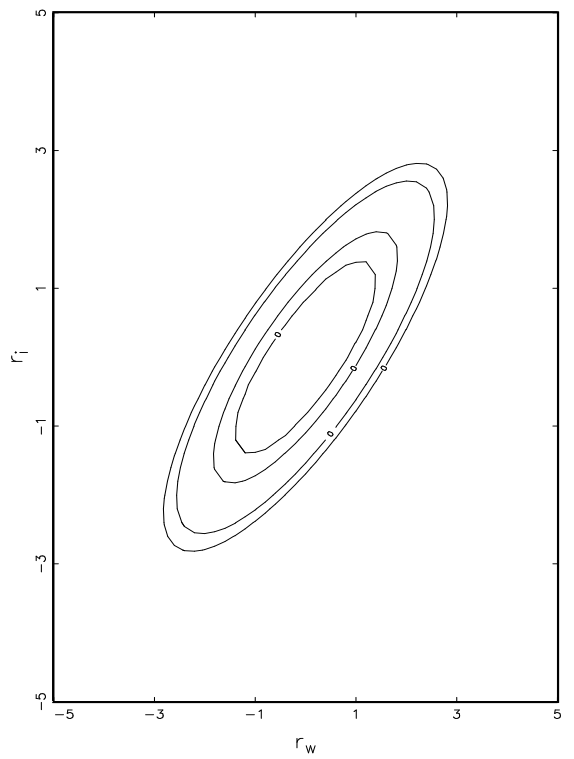

Figure 5: Market integration - bivariate normal with $(\rho=0.8) . \Psi=2.3270$.

(a) Distribution

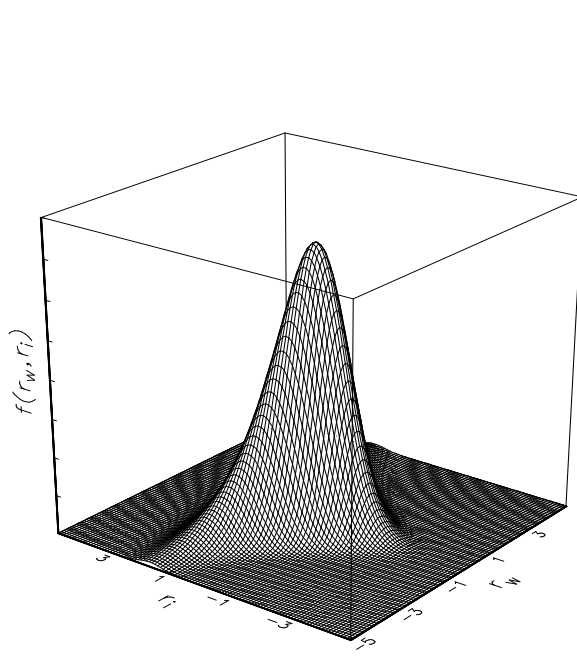

(b) Contour

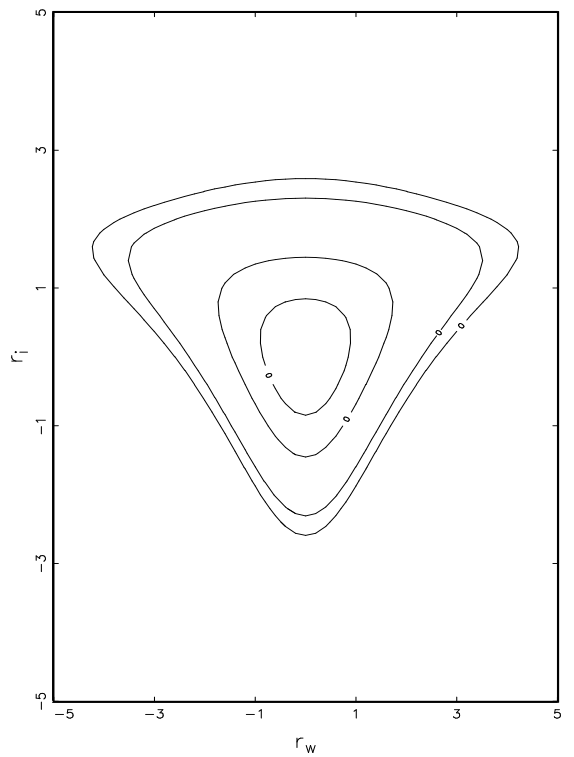

Figure 6: Market integration - bivariate generalized normal with $\left(\theta_{2}=0.4\right) . \quad \Psi=$ 2.2108 . 
at each point in time. This strategy has the advantage of yielding a time-varying measure of financial integration without imposing too many parametric restrictions on the underlying asset market model.

\section{Global Financial Integration}

The entropy measure of integration presented in Section 3 is now applied to the East Asian and ASEAN equity markets over the period January 1, 1997 to April 4, 2016. All estimates of integration are based on daily log-returns which are corrected for nonsynchronicity by filtering the returns using a 2-day moving average. To understand how integration within the two regions has changed over time a dynamic measure of integration is computed by performing the analysis over a rolling window beginning June 30, 1997 just prior to the start of the Asian financial crisis. Starting the rolling window at June 30, 1997 corresponds to a window width of 179 daily observations when measured with the start of the sample period of the filtered returns data.

\subsection{East Asia}

The countries included in the analysis of the equity markets of the East Asian region are China, Hong Kong, Japan, South Korea and Taiwan with the U.S. chosen as the measure of the global equity market. Figure 7 contains the estimate of the dynamic entropy measure of financial integration for the region by aggregating the bivariate entropy integration estimates between the equity markets of each country in East Asia and the world. After the Asian financial crisis in the 1997-98 the level of financial integration between East Asia and the world is relatively stable up until early 2003, followed by a period of general improvement ending early 2007. After which there is a continual deterioration in financial integration with the world peaking at the height of the Great recession in 2009. After 2009 there are general improvements in integration by 2011 where it reaches levels comparable to the integration levels experienced prior to the commencement of the Great Recession. For the post Great recessionary period integration returns to its pre-Great Recessionary levels apart from temporary deviations in 2011-12 during the European debt crisis and also at the very end of the sample in 2015-16, where there is a deterioration in financial integration.

To gain further insight into how global financial integration has changed for countries within East Asia, Figure 8 provides the bivariate dynamic integration measures 


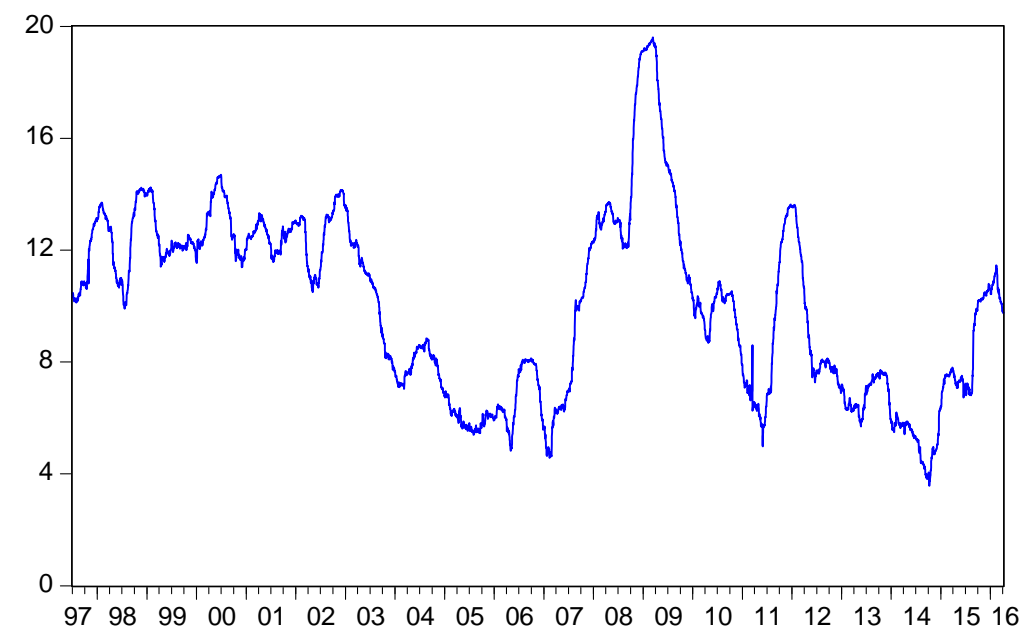

Figure 7: Rolling statistics of global equity integration of East Asia, June 30, 1997 to April 6, 2016.

between the U.S. and each of the 5 East Asian country equity markets. The country financial integration measures with the world all tend to move together, thereby providing further support for the regional measure given in Figure 7. A more formal measure of the link between the regional and country integration measures is given in Table 10 which provides a principal component decomposition of the correlation matrix of the 5 bivariate measures of global integration. Inspection of this table shows that the first principal component explains nearly $90 \%$ of the variation in the country integration measures with the U.S., with the estimated loadings being roughly equal in magnitude. Interestingly, Table 10 also shows that the second principal component which explains an additional $5 \%$ of total variability in integration with the U.S. is dominated by China and Japan, with no significant role played by Hong Kong, South Korea and Taiwan. More interestingly, the estimate of the loading on China is opposite to the loadings on Hong Kong, South Korea and Taiwan suggesting that there are also forces over the full sample period causing a wedge between the Chinese equity market and the equity markets of Hong Kong, South Korea and Taiwan. ${ }^{2}$

The dynamic entropy integration estimates for East Asia reported in Figures 7 and 8 are comparable to existing estimates reported in the literature. Kim and Lee (2012)

\footnotetext{
${ }^{2}$ Performing the principal component decomposition over a more recent period from January 2015 to April 2016 yields practically the same qualitative results as regards the estimated loadings and the proportion of total variation explained by each principal component.
} 
US-China

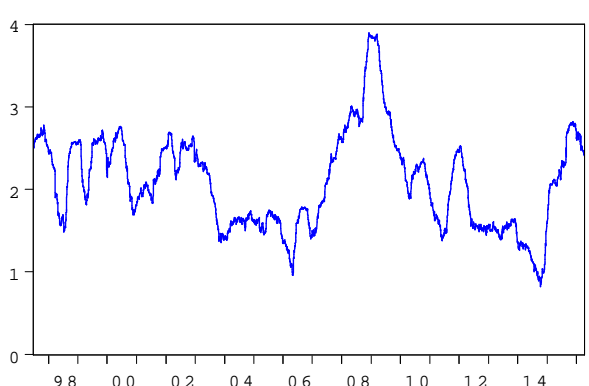

U S Japan

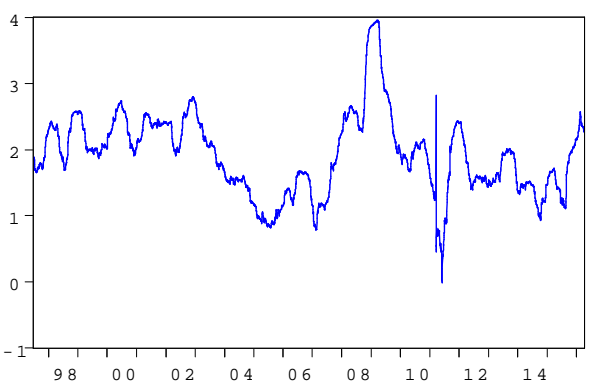

US-Taivan

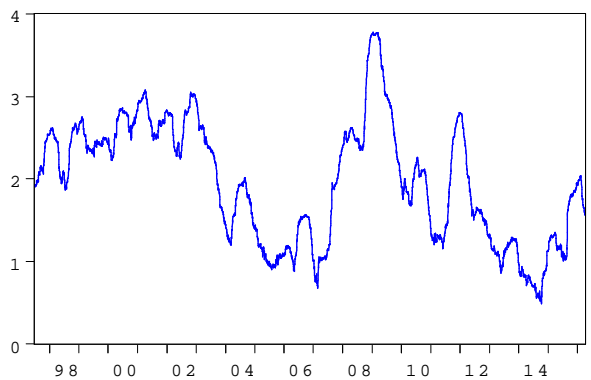

USHK

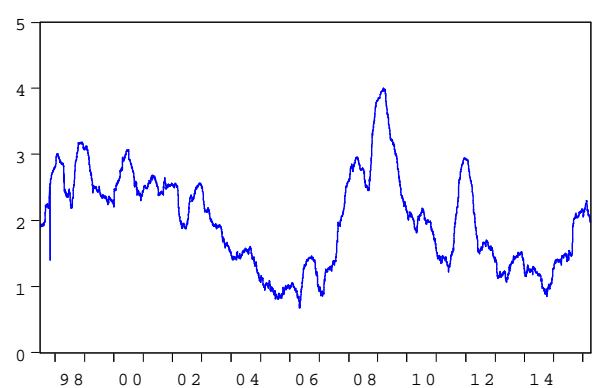

US -S outh Korea

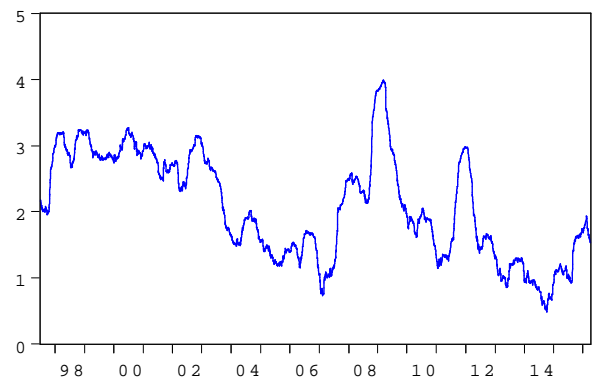

Figure 8: Rolling statistics of equity market integration of East Asian countries with the U.S., June 30, 1997 to April 6, 2016. 
Table 10:

Principal component decomposition of global equity integration in the East Asian region, June 30, 1997 to April 4, 2016.

\begin{tabular}{lrrrrr}
\hline \multirow{2}{*}{ Country } & \multicolumn{5}{c}{ Principal Components } \\
\cline { 2 - 6 } & PC1 & \multicolumn{1}{c}{ PC2 } & \multicolumn{1}{c}{ PC3 } & \multicolumn{1}{c}{ PC4 } & \multicolumn{1}{c}{ PC5 } \\
\hline China & 0.4173 & 0.8058 & 0.3629 & 0.1291 & 0.1673 \\
Hong Kong & 0.4628 & -0.0424 & -0.0248 & -0.8524 & -0.2380 \\
Japan & 0.4475 & 0.0778 & -0.8460 & 0.2137 & 0.1791 \\
South Korea & 0.4453 & -0.5285 & 0.3413 & 0.0818 & 0.6316 \\
Taiwan & 0.4614 & -0.2515 & 0.1878 & 0.4519 & -0.6958 \\
\hline Explained (\%) & 89.2200 & 6.2400 & 2.8200 & 1.1600 & 0.5500 \\
\hline
\end{tabular}

find an improvement in financial integration between East Asia and the U.S. after the East-Asian financial crisis in 1997-98 but before the start of the Great Recession mid2007, while Hyghebeart and Wang (2009) provide evidence that linkages between East Asian markets strengthened during a similar period. Apart from the use of second-order and higher order moments in computing the entropy measure of integration reported in Figure 7, this figure shows that the improvements in financial integration identified by Kim and Lee after the East Asian crisis were delayed by a few years with the main improvements occurring between 2003 and 2007. Using "uncertainty shocks" sourced in the U.S., Kido (2016) also finds evidence of a divergence between the U.S. and China during the Great recession when compared to the pre-crisis period. Interestingly, no significant differences between the two periods in the case of Japan and Korea are found using "uncertainty shocks" which is in contrast with the results based on the entropy measure of integration presented here in Figure 8.

\subsection{ASEAN}

The countries included in the analysis of the Asian region are Indonesia, Malaysia, the Philippines, Singapore and Thailand representing the ASEAN 5 countries, and the U.S. which again acts as a measure of global equity markets. Figure 9 provides the global measure of financial integration over time between the ASEAN equity markets and the world from June 30, 1997 from April 4, 2016. A comparison of Figures 7 and 9 shows that the changes in global integration of the two regions with the world tend to mirror each other, with the largest deterioration in financial integration occurring 


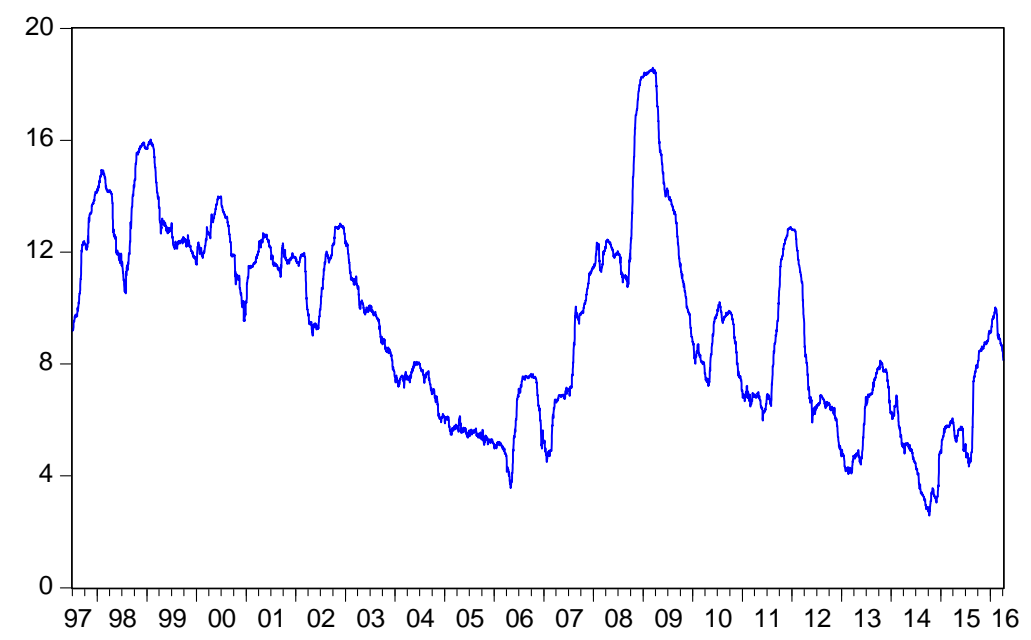

Figure 9: Rolling statistics of global equity integration of ASEAN, June 30, 1997 to April 6, 2016.

during the Great Recession and the European debt crisis. Global financial integration in the ASEAN region peaks in late 2014, which deteriorates over the next couple of years to integration levels comparable to just prior to the start of the East Asian crisis in mid 1997.

A breakdown of the global measure of financial integration for each of the ASEAN countries is presented in Figure 10 for the period June 30, 1997 to April 4, 2016. Inspection of the global equity integration measures for each country closely follow the aggregate measure given in Figure 9. This is also supported by the principal component decomposition results presented in Table 11 which show that the first principal component has estimated loadings that are roughly equal for all countries while explaining approximately $95 \%$ of variations in the country integration measures.

\section{Regional Integration and the Role of China}

This section focusses on regional integration amongst East Asia and ASEAN countries with special emphasis given to the role played by China. The Asian countries consist of Hong Kong, Japan, South Korea and Taiwan from East Asia and Indonesia, Malaysia, Philippines, Singapore and Thailand from the ASEAN set of countries, a total of 9 countries. The aggregate measure of integration between the Asia countries and China is given in Figure 11 for the period June 30, 1997 to April 4, 2016. 
U S -Indonesia

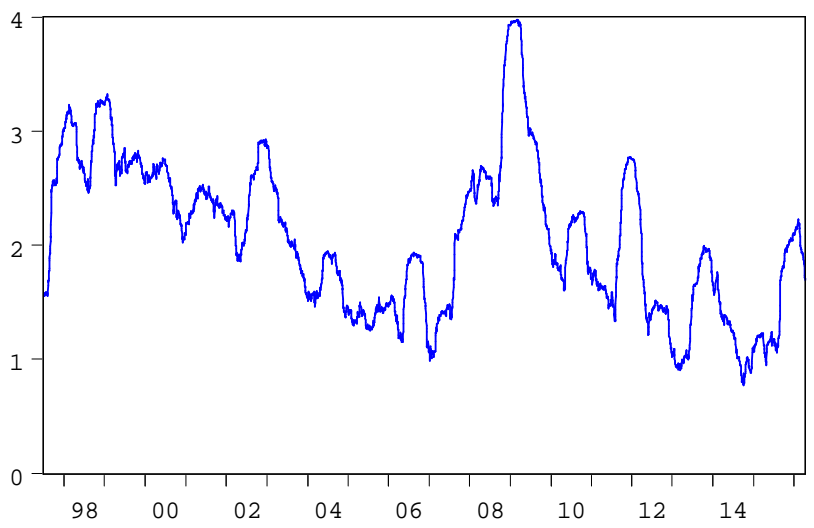

US - P hilippines

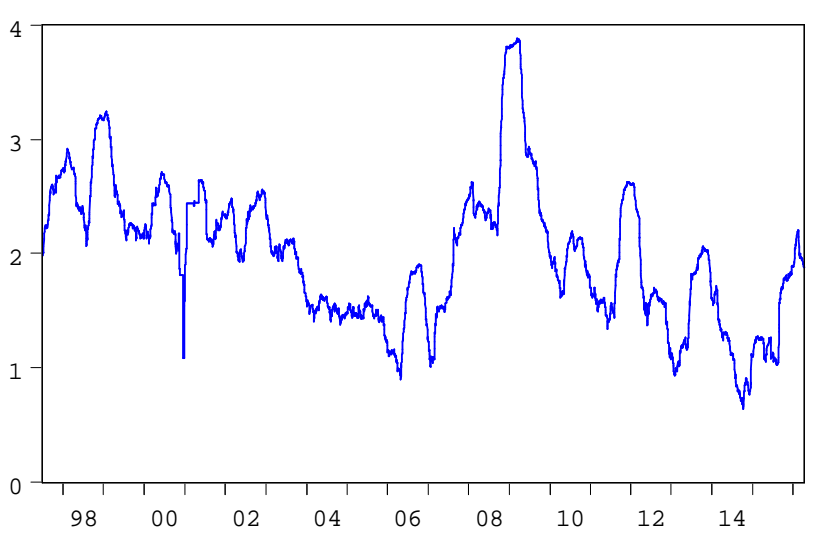

U S - Thailand

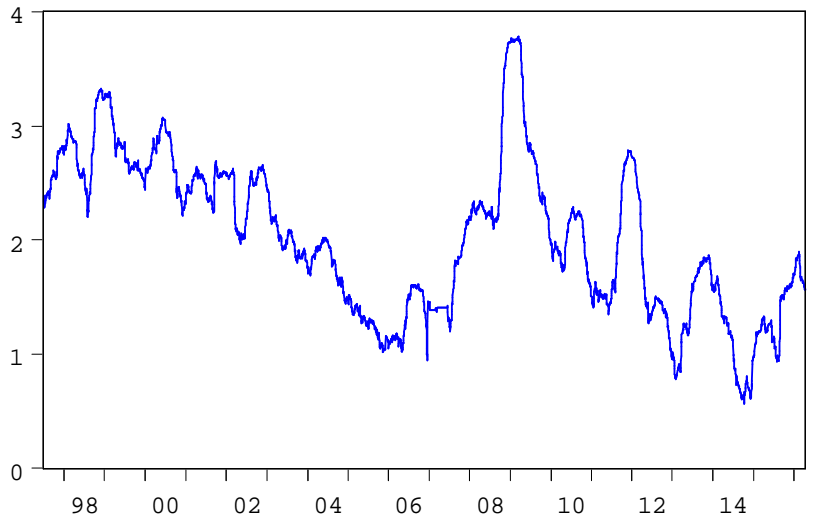

U S - M a laysia

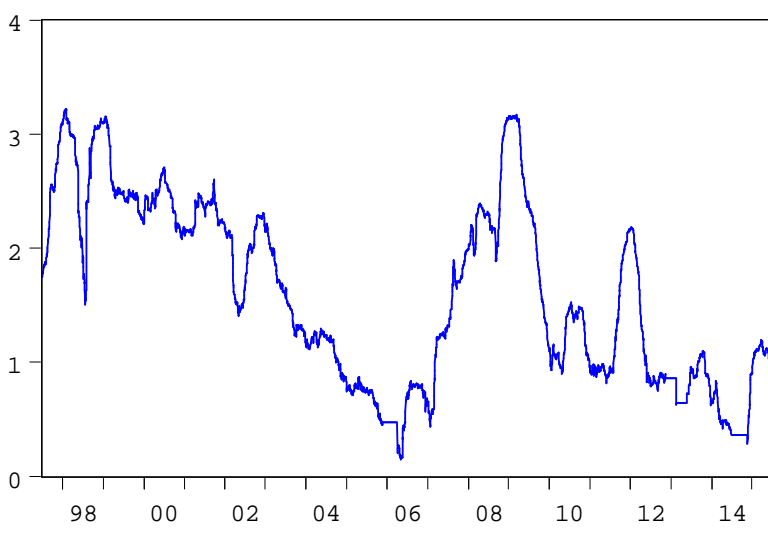

U S - S ingapore

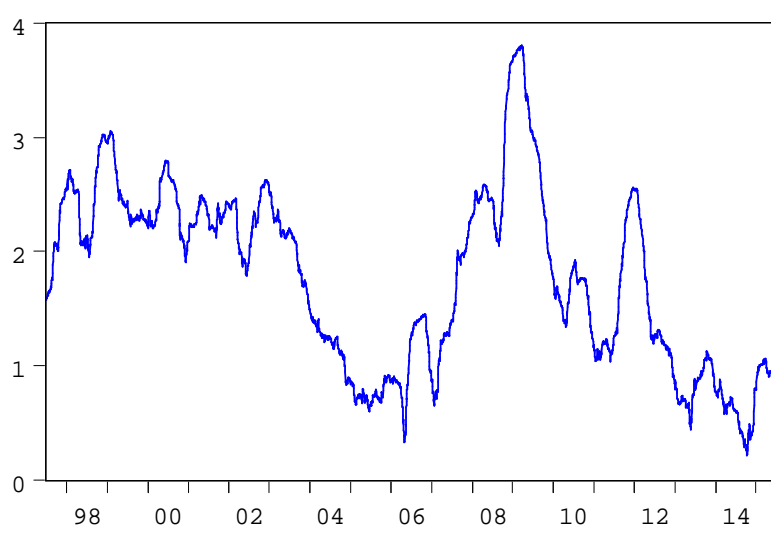

Figure 10: Rolling statistics of equity market integration of the ASEAN countries with the U.S., June 30, 1997 to April 6, 2016. 
Table 11:

Principal component decomposition of global equity integration in the ASEAN region, June 30, 1997 to April 4, 2016.

\begin{tabular}{lrrrrr}
\hline \multirow{1}{*}{ Country } & \multicolumn{5}{c}{ Principal Components } \\
\cline { 2 - 6 } & PC1 & \multicolumn{1}{c}{ PC2 } & \multicolumn{1}{c}{ PC3 } & \multicolumn{1}{c}{ PC4 } & \multicolumn{1}{c}{ PC5 } \\
\hline Indonesia & 0.4495 & -0.2870 & 0.0219 & -0.8391 & -0.1036 \\
Malaysia & 0.4411 & 0.7882 & 0.0798 & -0.0823 & 0.4133 \\
Philippines & 0.4466 & -0.5384 & -0.0302 & 0.3454 & 0.6247 \\
Singapore & 0.4491 & 0.0749 & -0.7389 & 0.2487 & -0.4298 \\
Thailand & 0.4495 & -0.0263 & 0.6679 & 0.3282 & -0.4931 \\
\hline Explained (\%) & 95.2700 & 2.1300 & 1.0800 & 0.7900 & 0.7300 \\
\hline
\end{tabular}

A comparison of the regional integration measure in Figure 11 and the global integration measures presented in Figure 7 for East Asia and in Figure 9 for the ASEAN region exhibit similar patterns. In particular, for the period prior to the start of the global financial crisis there is a general trend towards greater financial integration in the region. Once the Great recession begins there is an immediate deterioration in regional integration which peaks at the height of the global financial crisis in 2009. From this point onwards there are general improvements in integration to 2014 where the degree of financial integration reaches higher levels than experienced just prior to the commencement of the Great recession in mid-2007. However, from the end of 2014 to the end of the sample in April of 2016, there is again a sharp reduction in regional integration to levels experienced at the time of the East-Asian crisis in 1997-98.

To understand the changes in regional integration identified in Figure 11 the following regression equation is specified for each of the 9 country bivariate measures of integration with respect to China

$$
\Psi_{t}=\beta_{0}+\beta_{1} \ln \left(\frac{G D P_{t}}{G D P_{t}^{*}}\right)+\beta_{2} \Delta\left(\frac{C A C C_{t}}{N G D P_{t}}\right)+\beta_{3} \Delta\left(\frac{C A C C_{t}^{*}}{N G D P_{t}^{*}}\right)+\beta_{4}\left(r_{t}-r_{t}^{*}\right)+u_{t}
$$

where $\Psi_{t}$ represents the dynamic entropy measure of financial integration between the equity returns of a country and China, $\ln \left(G D P / G D P^{*}\right)$ is the natural logarithm of real GDP per capita in country $i$ relative to real GDP per capita in China expressed in USD, $\triangle(C A C C / N G D P)$ is the change in the ratio of the current account balance and nominal GDP of country $i, \Delta\left(C A C C^{*} / N G D P^{*}\right)$ is the change in the ratio of the current account balance and nominal GDP in China, $r-r^{*}$ is the nominal interest rate differential between country $i$ and China, and $u_{t}$ is a disturbance term. Equation 


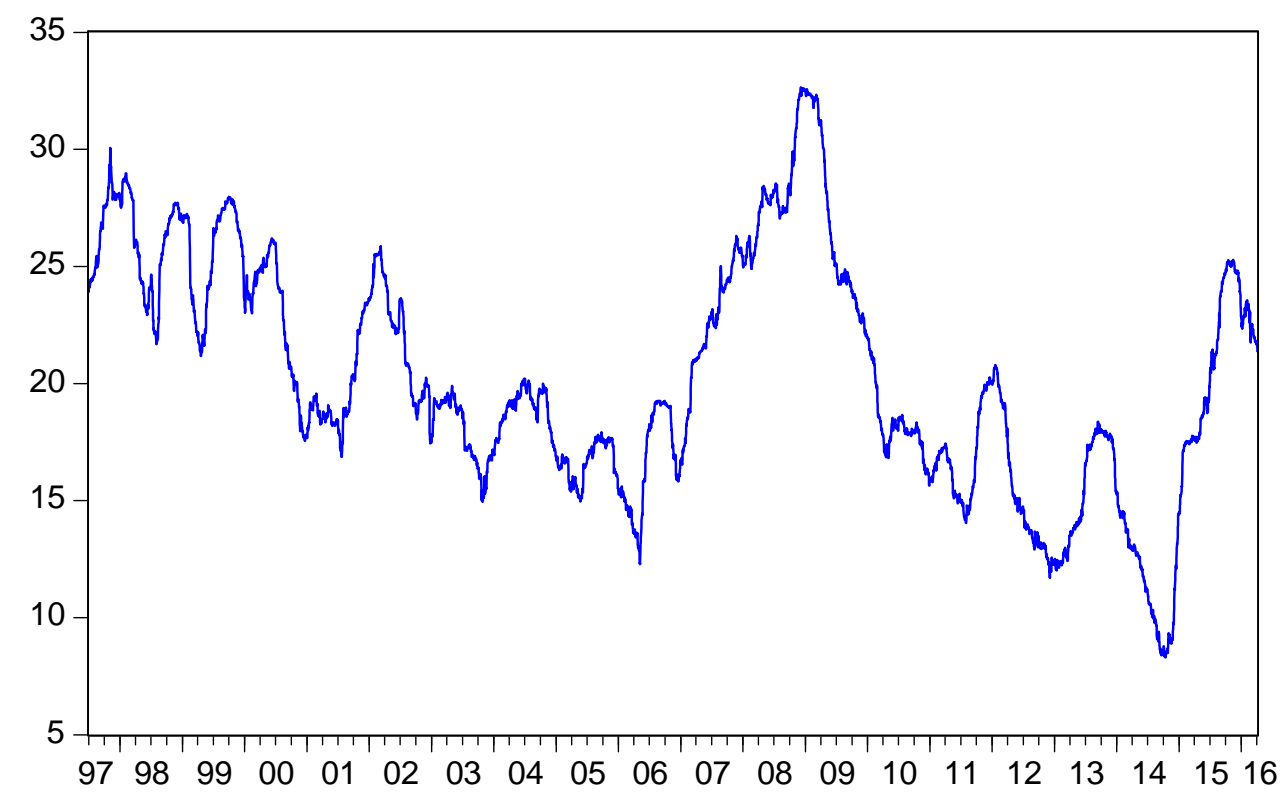

Figure 11: Rolling statistics of regional equity integration of East Asian and ASEAN countries with China as the benchmark, June 30, 1997 to April 6, 2016.

(9) allows for three broad potential channels of how regional financial integration in Asia has changed over time and draws on the preliminary indicators of integration explored in Section 2.1. The first channel identifies how changes in the relative size of output in each country impacts upon integration. The second identifies the importance of trade in affecting financial integration with the variables $\triangle(C A C C / N G D P)$ and $\Delta\left(C A C C^{*} / N G D P^{*}\right)$ capturing the relative importance of trade both domestically and within China. The third and final channel is given by the interest rate differential $r-r^{*}$, which identifies the role of capital mobility in affecting financial integration. The regression model in (9) is expanded in Appendix B to allow for the Chinn-Ito openness index presented in Table 7. In the case of Hong Kong and Singapore the results do not include an interest rate differential as the former country had a fixed exchange rate while the latter had an exchange rate based on a managed basket (Rajan, 2012).

The parameter estimates from estimating (9) for the 9 Asian countries are given in Table 12. Also presented are the results for the US-China entropy measure. To correct for potential endogeneity issues equation (9) is estimated by instrumental variables where the instruments are chosen as the 1-quarter lag of all variables in the model including the dependent and explanatory variables. As the entropy measures are based 
on estimated parameters quasi maximum likelihood (QMLE) standard errors are used. Finally, the frequency of the data is quarterly with the entropy measures converted from daily to quarterly by averaging the daily values over each quarter.

Inspection of Table 12 shows that the parameter estimates on $\ln \left(G D P / G D P^{*}\right)$ for most of the country entropy integration measures are positive and statistically significant indicating that there is strong evidence that the expansion of the Chinese economy has improved financial integration in Asia. The exceptions are Japan and the Philippines where the point estimates of $\beta_{1}$ in (9) are still positive, but not statistically significant. The countries with the relatively faster rates of convergence are Singapore with an estimate of $\beta_{1}$ just over 1.0, which translates into a convergence elasticity of $1.087 / 2.397=0.453$ per quarter, or 1.812 per annum based on the entropy value for Singapore in March of 2016. The countries with the next highest convergence rates are Korea, Thailand and Malaysia with estimates of $\beta_{1}$ between 0.8 and 1.0.

The parameter estimates on the Chinese current account variable $\Delta\left(C A C C^{*} / N G D P^{*}\right)$ show that trade is an important factor of financial integration. As all of the signs are negative there is strong evidence that expansions in trade with China in the region results in greater financial integration. This is not the case with domestic current account balances relative to nominal GDP $\triangle(C A C C / N G D P)$, which is not found to be an important determinant of integration with the exception of Japan. Interestingly, with the exception of Indonesia the empirical results also show that capital mobility is not an important factor in explaining changes in integration. Lee, Huh and Park (2013) also find a similar result and conclude that intra-regional asset trade is reflective of trade in goods.

The results of integration between the U.S. and China at the bottom of Table 12 show that trade is potentially the most important determinant of integration with increases in trade in China as reflected by an expansion of its current account, resulting in greater financial integration. Expansions of output in China relative to the U.S. also improve financial integration although the parameter estimate of $\beta_{1}$ is just statistically significant at the $10 \%$ level. In contrast, the other channels through the U.S. current account and the interest rate differential do not have a statistically significant effect on integration between the U.S. and China. 
Table 12:

Parameter estimates of the determinants of integration between China and selected countries in Asia and the US given by equation (9), December, 1997 to March, 2016.

The parentheses contain p-values using QMLE standard errors.

\begin{tabular}{|c|c|c|c|c|c|c|}
\hline \multirow[t]{2}{*}{ Country } & \multicolumn{5}{|c|}{ Determinant } & \multirow[b]{2}{*}{$\bar{R}^{2}$} \\
\hline & Const. & $\ln \left(\frac{G D P}{G D P^{*}}\right)$ & $\Delta\left(\frac{C A C C}{N G D P}\right)$ & $\Delta\left(\frac{C A C C^{*}}{N G D P^{*}}\right.$ & $r-r^{*}$ & \\
\hline Hong Kong & $\begin{array}{c}0.618 \\
(0.123)\end{array}$ & $\begin{array}{c}0.709 \\
(0.000)\end{array}$ & $\begin{array}{l}-0.058 \\
(0.608)\end{array}$ & $\begin{array}{l}-1.285 \\
(0.000)\end{array}$ & & 0.499 \\
\hline Japan & $\begin{array}{c}1.997 \\
(0.000)\end{array}$ & $\begin{array}{c}0.137 \\
(0.207)\end{array}$ & $\begin{array}{c}0.393 \\
(0.163)\end{array}$ & $\begin{array}{l}-0.985 \\
(0.000)\end{array}$ & $\begin{array}{c}0.031 \\
(0.390)\end{array}$ & 0.374 \\
\hline Korea & $\begin{array}{c}0.577 \\
(0.035)\end{array}$ & $\begin{array}{c}0.962 \\
(0.000)\end{array}$ & $\begin{array}{l}-0.001 \\
(0.993)\end{array}$ & $\begin{array}{l}-0.809 \\
(0.000)\end{array}$ & $\begin{array}{c}0.050 \\
(0.442)\end{array}$ & 0.655 \\
\hline Indonesia & $\begin{array}{c}2.342 \\
(0.000)\end{array}$ & $\begin{array}{c}0.371 \\
(0.010)\end{array}$ & $\begin{array}{c}0.222 \\
(0.178)\end{array}$ & $\begin{array}{l}-0.856 \\
(0.000)\end{array}$ & $\begin{array}{c}0.009 \\
(0.025)\end{array}$ & 0.418 \\
\hline Malaysia & $\begin{array}{c}1.156 \\
(0.000)\end{array}$ & $\begin{array}{c}0.822 \\
(0.003)\end{array}$ & $\begin{array}{c}0.173 \\
(0.115)\end{array}$ & $\begin{array}{l}-1.173 \\
(0.000)\end{array}$ & $\begin{array}{c}0.090 \\
(0.283)\end{array}$ & 0.451 \\
\hline Philippines & $\begin{array}{c}3.387 \\
(0.002)\end{array}$ & $\begin{array}{c}0.848 \\
(0.137)\end{array}$ & $\begin{array}{l}-0.058 \\
(0.597)\end{array}$ & $\begin{array}{l}-0.742 \\
(0.001)\end{array}$ & $\begin{array}{l}-0.065 \\
(0.536)\end{array}$ & 0.400 \\
\hline Singapore & $\begin{array}{l}-0.641 \\
(0.227)\end{array}$ & $\begin{array}{l}1.087 \\
(0.000)\end{array}$ & $\begin{array}{c}0.020 \\
(0.738)\end{array}$ & $\begin{array}{l}-1.310 \\
(0.000)\end{array}$ & & 0.468 \\
\hline Thailand & $\begin{array}{c}2.293 \\
(0.000)\end{array}$ & $\begin{array}{c}0.954 \\
(0.000)\end{array}$ & $\begin{array}{c}0.006 \\
(0.921)\end{array}$ & $\begin{array}{l}-0.948 \\
(0.000)\end{array}$ & $\begin{array}{c}(0.002) \\
0.935\end{array}$ & 0.462 \\
\hline U.S. & $\begin{array}{c}1.015 \\
(0.089)\end{array}$ & $\begin{array}{c}0.376 \\
(0.063)\end{array}$ & $\begin{array}{c}0.410 \\
(0.508)\end{array}$ & $\begin{array}{l}-1.160 \\
(0.000)\end{array}$ & $\begin{array}{c}-0.014 \\
(0.743)\end{array}$ & 0.414 \\
\hline
\end{tabular}




\section{Conclusions}

This paper applies a new framework based on entropy theory to model changes in financial integration over time in East Asia and ASEAN equity markets, both with the world and within the region. An important part of the methodology is that it allows for changes in integration to occur through higher order comoments of the joint returns distribution thereby improving upon methods based purely on just second order moments using correlations. A further advantage of the approach is that as it is based on the joint distribution of asset returns it is not reliant on having to specify a particular economic model.

Using daily data from January 1997 to April 2016 on equity returns of countries in East Asia and ASEAN as well as the U.S., the empirical results show strong evidence of greater global and regional financial integration in East Asia and ASEAN equity markets, with reversals in trend during the Great recession and the European debt crisis, as well as more recently between 2014 to 2016. The empirical results also show the importance of the Chinese economy in impacting upon financial integration both regionally and globally with trade being the most important determinant in improving financial integration over time. In contrast, capital mobility as modelled by interest differentials between countries in general was found to be statistically insignificant.

The goal of financial market integration is in some ways the most challenging aspect of a region developing into a strong unified unit. Full financial market integration requires capital mobility, a strong regulatory structure, low exchange rate volatility and a stable macroeconomy. All of these factors change over time as countries develop in each of these areas at different rates. However, it is generally accepted that there is a strong relationship between economic development and integration (Bekaert and Harvey, 1995). In fact, one of the caveats of the policy directions towards regional cooperation is that such policy movements should also be made to address the development divide between countries through acceleration of integration of some of the poorer countries in the region. The goals relating to integration in trade in particular have been the strongest part of the regional development strategies (Lee, Huh and Park, 2013), which is also supported by the results presented in this paper. 


\section{A Data Sources}

A description of the data and sources are contained in the following table.

Table 1A:

Data description

\begin{tabular}{cll}
\hline \hline Series/Country & Description & Source \\
\hline Equity indexes & & \\
China & SHCOMP index & Bloomberg \\
Japan & TPX index & Bloomberg \\
Hong Kong & HSI index & Bloomberg \\
Korea & KOSPI index & Bloomberg \\
Indonesia & JCI index & Bloomberg \\
Malaysia & KLCI Index & Bloomberg \\
Philippines & PCOMP Index & Bloomberg \\
Singapore & STI Index & Bloomberg \\
Thailand & SET Index & Bloomberg \\
U.S. & S\&P 500 index & Bloomberg
\end{tabular}

Gross domestic product per capita

All constant prices, national

WEO

currency, converted to USD

Current account balance to GDP ratio

All $\%$ WEO

Interest rate

China discount rate

FRED

Japan discount rate

FRED

Hong Kong fixed exchange rate,

no relevant interest rate

Korea discount rate

FRED

Indonesia

discount rate

CEIC, Fred

Malaysia

1997 to June 2005 use U.S. federal

CEIC, Fred

funds rate, spliced with the central

bank policy rate from July 2005

Philippines policy rate: month average: repurchase CEIC

Singapore fixed exchange rate,

no relevant interest rate

Thailand discount rate: end of period

CEIC

U.S. effective federal funds rate FRED

Openness

All Chinn-Ito index. 2014 and 2015

values are assumed unchanged

since 2013

http://web.pdx.edu/ ito/Chinn-Ito_website.htm 


\section{B Additional Empirical Results}

This section contains additional empirical results by extending the set of determinants of financial integration to include the Chinn-Ito openness index in Table 7 into the regression model in (9). The results from estimating the extended regression are given in the following table where openness is measured by the ratio of the Chinn-Ito openness index of a country relative to the openness of China $o / o^{*}$.

Parameter estimates of the determinants of integration between China and selected countries in Asia and the US given by equation (9), December, 1997 to March, 2016. The parentheses contain p-values using QMLE standard errors.

\section{Table2A:}

Parameter estimates of the determinants of integration between China and selected countries in Asia and the U.S. by augmenting equation (9) by the ratio of the Chinn-Ito index of openness of country $i$ to the openness of China, December, 1997 to March, 2016. The parentheses contain p-values using QMLE standard errors.

\begin{tabular}{lccccccc}
\hline \hline Country & \multicolumn{7}{c}{ Determinant } \\
\cline { 2 - 7 } & Const. & $\ln \frac{G D P}{G D P^{*}}$ & $\Delta \frac{C A C C}{G D P}$ & $\Delta \frac{C A C C^{*}}{G D P^{*}}$ & $r-r^{*}$ & $\frac{o}{O^{*}}$ & $\bar{R}^{2}$ \\
\hline Japan & -2.554 & 0.224 & 0.491 & -1.071 & -0.058 & -2.037 & 0.368 \\
& $(0.279)$ & $(0.103)$ & $(0.087)$ & $(0.000)$ & $(0.227)$ & $(0.045)$ & \\
Korea & -0.434 & 1.435 & -0.057 & -0.741 & 0.012 & -0.308 & 0.658 \\
& $(0.790)$ & $(0.063)$ & $(0.632)$ & $(0.000)$ & $(0.881)$ & $(0.540)$ & \\
Indonesia & 1.930 & -0.057 & 0.299 & -0.781 & 0.008 & -0.595 & 0.530 \\
& $(0.000)$ & $(0.752)$ & $(0.081)$ & $(0.000)$ & $(0.052)$ & $(0.001)$ & \\
Malaysia & 1.858 & 0.260 & 0.136 & -0.976 & 0.107 & -0.536 & 0.554 \\
& $(0.000)$ & $(0.425)$ & $(0.205)$ & $(0.000)$ & $(0.174)$ & $(0.003)$ & \\
Philippines & 4.257 & 0.832 & -0.169 & -0.719 & -0.181 & -0.742 & 0.516 \\
& $(0.000)$ & $(0.037)$ & $(0.118)$ & $(0.000)$ & $(0.028)$ & $(0.000)$ & \\
Singapore & -1.056 & 1.128 & 0.023 & -1.334 & & -0.157 & 0.463 \\
& $(0.280)$ & $(0.000)$ & $(0.707)$ & $(0.000)$ & & $(0.506)$ & \\
Thailand & 2.434 & 0.547 & -0.015 & -1.011 & 0.019 & -0.288 & 0.461 \\
& $(0.000)$ & $(0.321)$ & $(0.828)$ & $(0.000)$ & $(0.579)$ & $(0.392)$ & \\
\hline
\end{tabular}




\section{References}

[1] ASEAN (2008). ASEAN Economic Community Blueprint, ASEAN Secretariat, Jakarta.

[2] Athukorala, P.C., \& Yamashita, N. (2006). Production Fragmentation and Trade Integration: East Asia in a Global Context. The North American Journal of Economics and Finance, 17, 233-256.

[3] Beine, M., Cosma, A., \& Vermeulen, R. (2010). The Dark Side Of Global Integration: Increasing Tail Dependence. Journal of Banking and Finance, 34, 1, 184-192.

[4] Bekaert, G., \& Harvey, C. R. (1995). Time-Varying World Market Integration. The Journal of Finance, 50, 403-444.

[5] Bekaert, G., Harvey, C.R., \& Ng, A. (2005). Market Integration and Contagion. Journal of Business, 78, 1, 39-70.

[6] Cobb, L., Koppstein, P., \& Chen, N.H. (1983). Estimation and Moment Recursion Relations for Multimodal Distributions of the Exponential Family. Journal of the American Statistical Association, 78, 124-130.

[7] Chan, K.S., Dang, V.Q.T., \& Lai, J.T. (2016). Capital Market Integration in ASEAN: A Non-Stationary Panel Data Analysis. Paper presented at the 2016 ECU-YNU International Conference on China's Rise and Regional Integration in East Asia, Yokahama National University, Yokahama Japan, 8-9 July 2016.

[8] Chinn, M.D., \& Ito, H. (2006). What Matters for Financial Development? Capital Controls, Institutions, and Interactions. Journal of Development Economics, 81, 163-192.

[9] Chinn, M.D., \& Ito, H. (2008). A New Measure of Financial Openness. Journal of Comparative Policy Analysis, 10, 309-322.

[10] Diebold, F., \& Yilmaz, K. (2009). Measuring Financial Asset Return and Volatility Spillovers, with Application to Global Equity Markets. Economic Journal, Royal Economic Society, 119, 534, 158-71.

[11] Dumas, B., Harvey, C. R., \& Ruiz, P. (2003). Are Correlations Of Stock Returns Justified By Subsequent Changes In National Outputs? Journal of International Money and Finance, 22, 777-811.

[12] Engle, R. (2002). Dynamic Conditional Correlation: A Simple Class of Multivariate Generalized Autoregressive Conditional Heteroskedasticity Models. Journal of Business and Economic Statistics, 20, 339-350.

[13] Fratzscher, M. (2002). Financial Market Integration In Europe: On The Effects Of EMU On Stock Markets. International Journal of Finance and Economics, 7, 165-193. 
[14] Fry, R.A., Martin, V. L., \& Tang, C. (2010). A New Class of Tests of Contagion With Applications. Journal of Business and Economic Statistics, 28, 423-437.

[15] Fry-McKibbin, R.A., \& Hsiao C.Y-L. (2016). Extremal Dependence and Contagion. Econometric Reviews, 1-24.

[16] Fry-McKibbin, R.A., Martin, V. L., \& Tang, C. (2014). Financial Contagion and Asset Pricing. Journal of Banking and Finance, 47, 296-308.

[17] Gaulier, G., Lemoine, F., \& Ünal-Kesenci, D. (2007). China's Integration in East Asia: Production Sharing, FDI \& High-Tech Trade. Economic Change and Restructuring, 40, 27-63.

[18] Guillaumin, C. (2009). Financial Integration in East Asia: Evidence from Panel Unit Root and Panel Cointegration Tests. Journal of Asian Economics, 20, 314326.

[19] Haldane, A., \& Hall, S. (1991). Sterling's Relationship with the Dollar and the Deutschemark. Economic Journal, 101, 436-43.

[20] Harvey, C.R., \& Siddique, A. (2000). Conditional Skewness in Asset Pricing Tests. The Journal of Finance, 55, 1263-1295.

[21] Huyghebaert, N., \& Wang, L. (2010). The Co-movement of Stock Markets in East Asia: Did the 1997-1998 Asian Financial Crisis Really Strengthen Stock Market Integration? China Economic Review, 21, 98-112.

[22] Jeon, J., Oh, Y., \& Yang, D.Y. (2006). Financial Market Integration in East Asia: Regional or Global? Asian Economic Papers, 5, 73-89.

[23] Kido, Y. (2016). Spillover Effects of US Policy Uncertainty Shocks: Its Impact on Asian and Global Financial Market. Paper presented at the 2016 ECU-YNU International Conference on China's Rise and Regional Integration in East Asia, Yokahama National University, Yokahama Japan, 8-9 July 2016.

[24] Kim, S., \& Lee, J-W. (2012). Real and Financial Integration in East Asia. Review of International Economics, 20, 332-349.

[25] Kim, S., Lee, J-W., \& Shin, K. (2008). Regional and Global Financial Integration in East Asia. China, Asia and the New World Economy, Munich Personal RePEc Archive.

[26] Kim, S. J., Moshirian, F., \& Wu, E. (2005). Dynamic Stock Market Integration Driven By The European Monetary Union: An Empirical Analysis. Journal of Banking and Finance, 29(10), 2475-2502.

[27] Lee, H.H., Huh, H.S., \& Park, D. (2013). Financial Integration in East Asia: An Empirical Investigation. The World Economy, 36, 396-418. 
[28] Lien, D. (2016). Volatility Spillovers Among the U.S. and Asian Stock Markets During Financial Crises. Paper presented at the 2016 ECU-YNU International Conference on China's Rise and Regional Integration in East Asia, Yokahama National University, Yokahama Japan, 8-9 July 2016.

[29] Lye, J. N., \& Martin, V. L. (1993). Robust Estimation, Nonnormalities, And Generalized Exponential Distributions. Journal of the American Statistical Association, 88, 421, 261-267.

[30] Moore, T., \& Wang, P. (2014). Dynamic Linkage Between Real Exchange Rates and Stock Prices: Evidence from Developed and Emerging Asian Markets. International Review of Economics and Finance, 29, 1-11.

[31] Pukthuanthong, K., \& Roll, R. (2009). Global Market Integration: An Alternative Measure And Its Application. Journal of Financial Economics, 94, 214-232.

[32] Rajan, R.S. (2012). Management of Exchange Rate Regimes in Emerging Asia. Review of Development Finance, 2, 53-68.

[33] Sato, K., \& Shreshta, N. (2016). Global and Regional Shock Transmission - An Asian Perspective. Paper presented at the 2016 ECU-YNU International Conference on China's Rise and Regional Integration in East Asia, Yokahama National University, Yokahama Japan, 8-9 July 2016.

[34] Shin, K., \& Sohn, C.H. (2006). Trade and Financial Integration in East Asia: Effects on Co-movements. The World Economy, 29, 1649-1669.

[35] Smith, D.R. (2007). Conditional Coskewness and Asset Pricing. Journal of Empirical Finance, 14, 91-119.

[36] Sohn, C-H., \& Heo, J.H. (2016). The Effect of Free Trade Agreement on Foreign Direct Investment Inflows. Paper presented at the 2016 ECU-YNU International Conference on China's Rise and Regional Integration in East Asia, Yokahama National University, Yokahama Japan, 8-9 July 2016.

[37] Solnik, B., \& Roulet, J. (2000). Dispersion As Cross-Sectional Correlation. Financial Analyst Journal, 56, 54-61.

[38] Yi-fei, M., \& Fang, S.Y.L. (2016). A Gravity Analysis on the Tariff Cuts' Bilateral Trade Effect within the China-ASEAN Free Trade Area. Paper presented at the 2016 ECU-YNU International Conference on China's Rise and Regional Integration in East Asia, Yokahama National University, Yokahama Japan, 8-9 July 2016.

[39] Yu, I. W., Fung, K.P., \& Tam, C.S. (2010). Assessing Financial Market Integration in Asia - Equity Markets. Journal of Banking and Finance, 34, 2874-2885. 